\title{
New Di- and Triorganotin(IV) Tyrosylalaninates as Models for Metal—Protein Interactions: Synthesis, Structural Characterization, and Potentiometric Studies of Tyrosylalanine, Glycyltyrosine, and Glycylisoleucine with Di- and Trimethyltin(IV) Moieties in Aqueous Medium
}

\author{
Mala Nath, ${ }^{1}$ Sulaxna, ${ }^{1}$ Xueqing Song, ${ }^{2}$ and George Eng ${ }^{2}$ \\ ${ }^{1}$ Department of Chemistry, Indian Institute of Technology Roorkee, Roorkee 247667, India \\ ${ }^{2}$ Department of Chemistry and Physics, University of the District of Columbia, Washington, DC 20008, USA
}

Correspondence should be addressed to Mala Nath, malanfcy@iitr.ernet.in

Received 6 January 2012; Accepted 1 February 2012

Academic Editors: L. Jerzykiewicz and M. I. M. Wazeer

Copyright () 2012 Mala Nath et al. This is an open access article distributed under the Creative Commons Attribution License, which permits unrestricted use, distribution, and reproduction in any medium, provided the original work is properly cited.

\begin{abstract}
Di- and triorganotin(IV) derivatives of tyrosylalanine ( $\mathrm{H}_{2}$ Tyr-Ala) with general formula $\mathrm{R}_{2} \mathrm{Sn}$ (Tyr-Ala) (where $\mathrm{R}=\mathrm{Me}, n$-Bu, $n$ Oct, and $\mathrm{Ph}$ ) and $\mathrm{R}_{3} \mathrm{Sn}(\mathrm{HTyr}-\mathrm{Ala}$ ) (where $\mathrm{R}=\mathrm{Me}$ and $\mathrm{Ph}$ ) have been synthesized and structurally characterized in the solid state as well as in solution on the basis of various spectroscopic techniques, namely. FT-IR, multinuclear $\left({ }^{1} \mathrm{H},{ }^{13} \mathrm{C}\right.$ and $\left.{ }^{119} \mathrm{Sn}\right) \mathrm{NMR}$ and ${ }^{119} \mathrm{Sn}$ Mössbauer. These investigations suggest that tyrosylalanine in $\mathrm{R}_{2} \mathrm{Sn}$ (Tyr-Ala) acts as dianionic tridentate ligand coordinating through carboxylate oxygen $\left[-\mathrm{C}(\mathrm{O}) \mathrm{O}^{-}\right]$, amino $\left(-\mathrm{NH}_{2}\right)$, and $(\mathrm{CO}) \mathrm{N}_{\text {peptide }}^{-}$nitrogen, while in the case of $\mathrm{R}_{3} \mathrm{Sn}(\mathrm{HTyr}-\mathrm{Ala})$, the ligand acts as monoanionic bidentate coordinating through $-\mathrm{C}(\mathrm{O}) \mathrm{O}^{-}$and $-\mathrm{NH}_{2}$, and the polyhedron around tin in $\mathrm{R}_{2} \mathrm{Sn}(\mathrm{Tyr}-$ Ala) and $\mathrm{R}_{3} \mathrm{Sn}(\mathrm{HTyr}-\mathrm{Ala})$ is a distorted trigonal-bipyramidal. Equilibrium (pH-metric) studies of the interaction of $\mathrm{Me}_{2} \mathrm{Sn}(\mathrm{IV})^{2+}$ and $\mathrm{Me}_{3} \mathrm{Sn}(\mathrm{IV})^{+}$with dipeptides namely, tyrosylalanine $\left(\mathrm{H}_{2}\right.$ Tyr-Ala), glycyltyrosine $\left(\mathrm{H}_{2} \mathrm{Gly}\right.$-Tyr $)$, and glycylisoleucine $\left(\mathrm{H}_{2} \mathrm{Gly}\right.$-Ile), in aqueous solution $\left(I=0.1 \mathrm{M} \mathrm{KNO}_{3}, 298 \mathrm{~K}\right)$ have also been carried out. The concentration distribution of the various complex species in solution has been evaluated as a function of $\mathrm{pH}$. It has been found that in these dipeptides, $\left[-\mathrm{C}(\mathrm{O}) \mathrm{O}^{-}, \mathrm{N}^{-}, \mathrm{NH}_{2}\right]$ coordinated complexes are dominant in the neutral $\mathrm{pH}$ range with a trigonal-bipyramidal structure. The complex species formed are water soluble in the $\mathrm{pH}$ range 2.7-10.5. In all of the studied systems, no polymeric species have been detected in the experimental $\mathrm{pH}$ range. Beyond $\mathrm{pH}$ 8.0, significant amounts of hydroxo species, namely. $\mathrm{Me}_{3} \mathrm{Sn}(\mathrm{OH})$ and $\mathrm{Me}_{2} \mathrm{Sn}(\mathrm{OH})_{2}$, are formed.
\end{abstract}

\section{Introduction}

Organotin compounds have emerged as potential future pharmaceuticals as antitumor agents among nonplatinum chemotherapeutic metallopharmaceuticals in the last two decades [1-5]. Though tin-based drugs usually are less active than the corresponding platinum antitumor drugs, however, they have the advantage of lower toxicity [6]. In order to get a better insight in how the organotin species behave inside the biological systems, it is necessary to study their coordination behavior with biomolecules that can occur in the biological medium. Therefore, considerable efforts have been made to understand the binding mode of organotin compounds with biologically relevant ligands such as amino acids $[1,2,7-13]$ and dipeptides $[1,2,12-$ 24], which constitute a very important class of biomolecules. Further, diorganotin(IV) derivatives of dipeptides [12, 14, 18] have been found to exhibit potent anti-inflammatory activity; thus such compounds may hold the potential to be placed in the class of nonsteroidal anti-inflammatory drugs (NSAIDs).

Peptides or proteins are well known efficient metal ion binders, and their interaction with organotin cations may play an important role in the mechanism of their toxic and antitumor effect. Model studies using small peptides as low-molecular-weight protein mimics may furnish essential 
details on the metal ion-protein interactions. Several investigations are directed at exploring the coordination chemical behavior of di- and triorganotin(IV) cations towards amino acids [1, 2, 7-13], dipeptides [1, 2, 12-24], or tripeptides [12, $25,26]$ in the solid state. However, a few works focused on the solution equilibrium studies for such systems [27-30] which could provide essential information on the biospeciation of organotin moiety and thus on its bioavailability. Therefore, the in vitro speciation of organotin compounds with hetero donor $(\mathrm{N}, \mathrm{O}$, or S-containing) ligands is indispensable and important due to the implication of organotin compounds in cancer prophylaxis and other physiological processes, and it may also be useful for the further modeling of organotin binding to macromolecular compounds.

In view of this, herein we report the synthesis and structural studies of di- and triorganotin(IV) derivatives of tyrosylalanine ( $\left.\mathrm{H}_{2} \mathrm{Tyr}-\mathrm{Ala}\right)$. The structure of these derivatives is discussed with special focus on the possible modes of coordination. Apart from this, the interaction of $\mathrm{Me}_{n} \mathrm{Sn}^{(4-n)+}$ (where $n=2$ or 3 ) with dipeptides, namely, tyrosylalanine $\left(\mathrm{H}_{2} \mathrm{Tyr}-\mathrm{Ala}\right)$, glycyltyrosine $\left(\mathrm{H}_{2} \mathrm{Gly}-\mathrm{Tyr}\right)$, and glycylisoleucine ( $\mathrm{H}_{2}$ Gly-Ile), has been performed in aqueous solution at $298 \pm 0.1 \mathrm{~K}$ and at an ionic strength $(I)$ of $0.1 \mathrm{M}$ of $\mathrm{KNO}_{3}$ in the $\mathrm{pH}$ range $2.0-10.5$. In this paper, the equilibrium behavior and possible structures of the complex species formed under experimental conditions have been discussed on the basis of $\mathrm{pH}$-metric titrations.

\section{Experimental}

2.1. Materials and Physical Measurements. All the syntheses were carried out under anhydrous nitrogen atmosphere, and the precautions to avoid the presence of oxygen were taken at every stage. Solvents were dried and stored under nitrogen before use. Dimethyltin(IV) dichloride, di- $n$ butyltin(IV) dichloride, di-n-octyltin(IV) oxide (Aldrich), trimethyltin(IV) chloride and triphenyltin(IV) chloride (Merck-Schuchardt), tetraphenyltin(IV) (Sigma-Aldrich), tin tetrachloride (Farmitalia Carlo Erba) and tyrosylalanine ( $\mathrm{H}_{2}$ Tyr-Ala), glycyltyrosine $\left(\mathrm{H}_{2} \mathrm{Gly}-\mathrm{Tyr}\right)$, and glycylisoleucine $\left(\mathrm{H}_{2}\right.$ Gly-Ile) (Sigma-Aldrich) were used as received. Diphenyltin(IV) dichloride was synthesized according to the reported method [31].

All the physicochemical and spectral measurements were carried out using the same methods and instruments reported previously [32]. ${ }^{1} \mathrm{H}-{ }^{13} \mathrm{C}$ heteronuclear single quantum correlation (HSQC) and ${ }^{1} \mathrm{H}-{ }^{13} \mathrm{C}$ heteronuclear multiple-bond correlation (HMBC) NMR spectra of $\mathrm{Ph}_{2} \mathrm{Sn}$ (Tyr-Ala) were recorded on a Bruker Avance $500 \mathrm{MHz}$ NMR spectrometer at the Indian Institute of Technology Roorkee, Roorkee, India. HSQC and HMBC experiments were carried out at $298 \mathrm{~K}$ in $\mathrm{D}_{2} \mathrm{O}$ using DSS as internal standard. Typical parameters for 2D experiments were 10242048 data points along t2 dimension, 512 free induction decays in $\mathrm{t} 1$ dimension, pulse width $\sim 7.7 \mu \mathrm{s}$, spectral width $6000 \mathrm{~Hz}\left({ }^{1} \mathrm{H}\right) / 24,000 \mathrm{~Hz}\left({ }^{13} \mathrm{C}\right)$, number of scans 64 , digital resolution $3.0 \mathrm{~Hz} /$ point, and relaxation delay $2.0 \mathrm{~s}$. Data were zero-filled in F1 dimension before the Fourier transformation. Sine squared bell window function was applied before processing the FIDs. Potentiometric studies were performed under similar experimental conditions and using SCOGS software as reported previously [33].

2.2. Syntheses of Di- and Triorganotin(IV) Tyrosylalaninates by Sodium Salt Method. Tyrosylalanine ( $2.0 \mathrm{mmol}, 0.252 \mathrm{~g}$ ) was dissolved in the minimum amount $(20 \mathrm{~mL})$ of specially dried methanol under dry nitrogen and added to sodium methoxide, prepared by reacting sodium ( $\sim 4.2$ equivalent) for diorganotin(IV) derivatives/( $\sim 2.2$ equivalent $)$ for triorganotin(IV) derivatives with dry methanol $(10 \mathrm{~mL})$. The resulting mixture was first stirred at room temperature for $30 \mathrm{~min}$ and then refluxed for 5-6 h with constant stirring to give a clear solution of $\mathrm{Na}_{2} \mathrm{Tyr}-\mathrm{Ala} / \mathrm{NaHTyr}-\mathrm{Ala}$. A hot methanol solution $(20 \mathrm{~mL})$ of $\mathrm{R}_{2} \mathrm{SnCl}_{2} / \mathrm{R}_{3} \mathrm{SnCl}(\sim 2.0 \mathrm{mmol})$ was added to the solution of the preformed sodium salt of $\mathrm{H}_{2} \mathrm{Tyr}-\mathrm{Ala}$. The resulting mixture was further refluxed with constant stirring for another $14-16 \mathrm{~h}$ except for diand trimethyltin(IV) derivatives, for which only constant stirring was carried out at room temperature $\left(30 \pm 2{ }^{\circ} \mathrm{C}\right)$ under dry nitrogen atmosphere. The reaction mixture was then centrifuged and filtered in order to remove the sodium chloride formed. The excess of solvent was removed under reduced pressure, and the solid product thus obtained was recrystallized from either methanol-hexane $(1: 1 \mathrm{v} / \mathrm{v})$ or methanol-petroleum ether $\left(\mathrm{bp} 40-60^{\circ} \mathrm{C}\right)(1: 3, \mathrm{v} / \mathrm{v})$ mixture.

2.3. Synthesis of Di-n-octyltin(IV) Tyrosylalaninate by the Azeotropic Removal of Water Method. Di-n-octyltin(IV) tyrosylalaninate was prepared under anhydrous nitrogen atmosphere by dropwise addition of a dry, hot methanol solution ( $2.0 \mathrm{mmol}, 0.252 \mathrm{~g}, \sim 25 \mathrm{~mL}$ ) of tyrosylalanine to the suspension of di- $n$-octyltin(IV) oxide $(2.0 \mathrm{mmol}, 0.248 \mathrm{~g}$ ) in benzene. The reaction mixture obtained was refluxed with constant stirring, giving a clear solution within $2 \mathrm{~h}$. Refluxing was continued at least for $16-18 \mathrm{~h}$ with azeotropic removal of water by the Dean-Stark apparatus. The solution was filtered, and the excess of solvent was removed under reduced pressure and allowed to cool. The solid product thus obtained was recrystallized by using methanol-hexane mixture $(1: 1, \mathrm{v} / \mathrm{v})$.

\section{Results and Discussion}

Reactions of $\mathrm{R}_{2} \mathrm{SnCl}_{2}(\mathrm{R}=\mathrm{Me}, n-\mathrm{Bu}$ and $\mathrm{Ph})$ and $\mathrm{R}_{3} \mathrm{SnCl}$ $\left(\mathrm{R}=\mathrm{Me}\right.$ and $\mathrm{Ph}$ ) with the sodium salt of $\mathrm{H}_{2}$ Tyr-Ala (formed according to (1)) in a $1: 1$ molar ratio led to the formation of di- and triorganotin(IV) tyrosylalaninates according to (2) and (3), respectively. Di- $n$-octyltin(IV) oxide reacts with $\mathrm{H}_{2}$ Tyr-Ala in equimolar ratio in dry methanol to give di$n$-octyltin(IV) tyrosylalaninate with azeotropic removal of water (equation (4); Scheme 1)

$$
\begin{gathered}
\mathrm{H}_{2} \text { Tyr-Ala }+x \mathrm{NaOMe} \longrightarrow \mathrm{Na}_{2}(\text { Tyr-Ala }) / \mathrm{Na}(\text { HTyr-Ala }) \\
+x \mathrm{MeOH}
\end{gathered}
$$

(where $x=1,2$ ) 


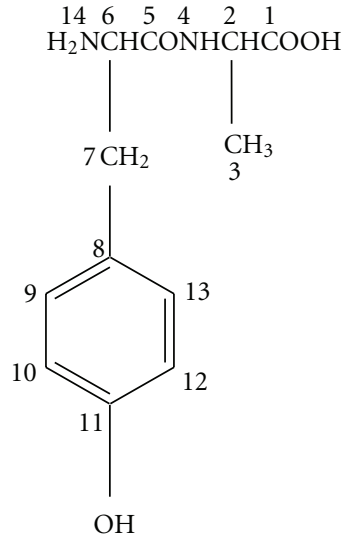

$\mathrm{H}_{2}$ Tyr-Ala

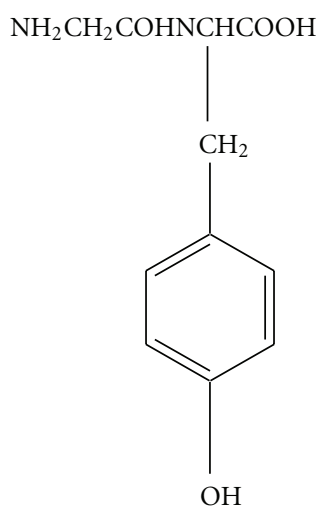

$\mathrm{H}_{2} \mathrm{Gly}-\mathrm{Tyr}$

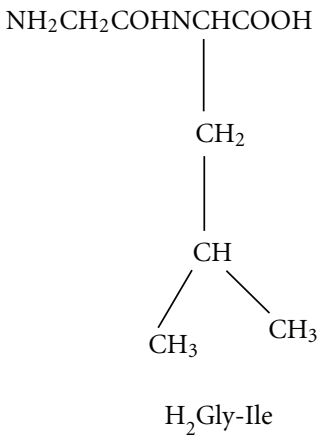

Scheme 1: Numbering scheme of $\mathrm{H}_{2}$ Tyr-Ala and chemical formulae of $\mathrm{H}_{2}$ Gly-Tyr and $\mathrm{H}_{2}$ Gly-Ile.

TABLE 1: Analytical data of di- and triorganotin(IV) tyrosylalaninates.

\begin{tabular}{|c|c|c|c|c|c|c|c|c|}
\hline \multirow{2}{*}{ Compound (empirical formula) } & \multirow{2}{*}{ Yield (\%) } & \multirow{2}{*}{$\begin{array}{l}\text { Color and } \\
\text { physical state }\end{array}$} & \multirow{2}{*}{ m.p. $\left({ }^{\circ} \mathrm{C}\right)$} & \multicolumn{5}{|c|}{ Analysis (\%): found (calculated) } \\
\hline & & & & $\mathrm{C}$ & $\mathrm{H}$ & $\mathrm{N}$ & $\mathrm{O}$ & Sn \\
\hline $\mathrm{Me}_{2} \mathrm{Sn}($ Tyr-Ala $)\left[\mathrm{C}_{14} \mathrm{H}_{20} \mathrm{~N}_{2} \mathrm{O}_{4} \mathrm{Sn}\right]$ & 60 & Yellow solid & $210(\mathrm{dec})$ & $\begin{array}{c}42.10 \\
(42.14)\end{array}$ & $\begin{array}{c}4.98 \\
(5.05)\end{array}$ & $\begin{array}{c}6.96 \\
(7.02)\end{array}$ & $\begin{array}{c}15.94 \\
(16.04)\end{array}$ & $\begin{array}{c}29.69 \\
(29.75)\end{array}$ \\
\hline$n-\mathrm{Bu}_{2} \mathrm{Sn}(\mathrm{Tyr}-\mathrm{Ala})\left[\mathrm{C}_{20} \mathrm{H}_{32} \mathrm{~N}_{2} \mathrm{O}_{4} \mathrm{Sn}\right]$ & 71 & White solid & $153-155$ & $\begin{array}{c}49.68 \\
(49.71)\end{array}$ & $\begin{array}{c}6.63 \\
(6.68)\end{array}$ & $\begin{array}{c}5.76 \\
(5.80)\end{array}$ & $\begin{array}{c}13.20 \\
(13.24)\end{array}$ & $\begin{array}{c}24.50 \\
(24.57)\end{array}$ \\
\hline$n$-Oct ${ }_{2} \mathrm{Sn}(\mathrm{Tyr}-\mathrm{Ala})\left[\mathrm{C}_{28} \mathrm{H}_{48} \mathrm{~N}_{2} \mathrm{O}_{4} \mathrm{Sn}\right]$ & 79 & White solid & $156-160$ & $\begin{array}{c}56.42 \\
(56.48)\end{array}$ & $\begin{array}{c}8.08 \\
(8.13)\end{array}$ & $\begin{array}{c}4.63 \\
(4.70)\end{array}$ & $\begin{array}{c}10.70 \\
(10.75)\end{array}$ & $\begin{array}{c}19.89 \\
(19.94)\end{array}$ \\
\hline $\mathrm{Ph}_{2} \mathrm{Sn}(\mathrm{Tyr}-\mathrm{Ala})\left[\mathrm{C}_{24} \mathrm{H}_{24} \mathrm{~N}_{2} \mathrm{O}_{4} \mathrm{Sn}\right]$ & 69 & White solid & $168-170$ & $\begin{array}{c}55.04 \\
(55.10)\end{array}$ & $\begin{array}{c}4.58 \\
(4.62)\end{array}$ & $\begin{array}{c}5.31 \\
(5.35)\end{array}$ & $\begin{array}{c}12.18 \\
(12.23)\end{array}$ & $\begin{array}{c}22.61 \\
(22.70)\end{array}$ \\
\hline $\mathrm{Me}_{3} \mathrm{Sn}(\mathrm{HTyr}-\mathrm{Ala})\left[\mathrm{C}_{15} \mathrm{H}_{24} \mathrm{~N}_{2} \mathrm{O}_{4} \mathrm{Sn}\right]$ & 46 & Brown solid & $183-185$ & $\begin{array}{c}43.38 \\
(43.40)\end{array}$ & $\begin{array}{c}5.80 \\
(5.83)\end{array}$ & $\begin{array}{c}6.71 \\
(6.75)\end{array}$ & $\begin{array}{c}15.39 \\
(15.42)\end{array}$ & $\begin{array}{c}28.58 \\
(28.61)\end{array}$ \\
\hline $\mathrm{Ph}_{3} \mathrm{Sn}(\mathrm{HTyr}-\mathrm{Ala})\left[\mathrm{C}_{30} \mathrm{H}_{30} \mathrm{~N}_{2} \mathrm{O}_{4} \mathrm{Sn}\right]$ & 55 & $\begin{array}{l}\text { Light yellow } \\
\text { solid }\end{array}$ & $128-130$ & $\begin{array}{c}59.89 \\
(59.92)\end{array}$ & $\begin{array}{c}4.98 \\
(5.03)\end{array}$ & $\begin{array}{c}4.61 \\
(4.65)\end{array}$ & $\begin{array}{c}10.59 \\
(10.64)\end{array}$ & $\begin{array}{c}19.68 \\
(19.74)\end{array}$ \\
\hline
\end{tabular}

$$
\mathrm{R}_{2} \mathrm{SnCl}_{2}+\mathrm{Na}_{2}(\text { Tyr-Ala }) \longrightarrow \mathrm{R}_{2} \mathrm{Sn}(\text { Tyr-Ala })+2 \mathrm{NaCl}
$$

(where $\mathrm{R}=\mathrm{Me}, n$-Bu and $\mathrm{Ph}$ )

$$
\mathrm{R}_{3} \mathrm{SnCl}+\mathrm{Na}(\mathrm{HTyr}-\mathrm{Ala}) \longrightarrow \mathrm{R}_{3} \mathrm{Sn}(\mathrm{HTyr}-\mathrm{Ala})+\mathrm{NaCl}
$$

(where $\mathrm{R}=\mathrm{Me}$ and $\mathrm{Ph}$ )

$$
n-\mathrm{Oct}_{2} \mathrm{SnO}+\mathrm{H}_{2} \mathrm{Tyr}-\mathrm{Ala} \longrightarrow n-\mathrm{Oct}_{2} \mathrm{Sn}(\mathrm{Tyr}-\mathrm{Ala})+\mathrm{H}_{2} \mathrm{O} \text {. }
$$

The above reactions were found to be quite feasible, and di- and triorganotin(IV) tyrosylalaninates (except $n$ $\mathrm{Oct}_{2} \mathrm{Sn}(\mathrm{Tyr}-\mathrm{Ala})$ ) were synthesized within $\sim 19-22 \mathrm{~h}$ of refluxing. However, the reaction involving the synthesis of $n$-Oct ${ }_{2} \mathrm{Sn}$ (Tyr-Ala) yielded a turbid solution after prolonged heating, and the solid was obtained from the filtrate after removing the unreacted dipeptide/di- $n$-octyltin(IV) oxide. The resulting derivatives were obtained in $46-79 \%$ yield. All of the derivatives are found to be stable toward air and moisture. Most of the synthesized derivatives are soluble in methanol, but sparingly soluble in chloroform and other common organic solvents upon heating. The analytical data of all the synthesized derivatives (as presented in Table 1) suggest that in every instance the resulting derivatives crystallized with $1: 1$ stoichiometry regardless of the proportions of the organotin moiety and $\mathrm{H}_{2}$ Tyr-Ala used.

3.1. Infrared Spectroscopy. The characteristic infrared absorption frequencies (in $\mathrm{cm}^{-1}$ ) and their assignments for noncoordinated $\mathrm{H}_{2}$ Tyr-Ala and di- and triorganotin(IV) tyrosylalaninates are presented in Table 2 . There are several bands due to $v(\mathrm{O}-\mathrm{H}), v(\mathrm{~N}-\mathrm{H})$, and $v(\mathrm{C}-\mathrm{H})$ in the region $3571-2924 \mathrm{~cm}^{-1}$. It is difficult to differentiate between $\nu(\mathrm{O}-\mathrm{H}), \nu(\mathrm{N}-\mathrm{H})$, and $\nu(\mathrm{C}-\mathrm{H})$ stretching vibrations with certainty. For $\mathrm{H}_{2} \mathrm{Tyr}-\mathrm{Ala}$, broadening occurs in the region $3440-3180 \mathrm{~cm}^{-1}$, which indicates either the overlapping of $\nu(\mathrm{O}-\mathrm{H})$ and $\nu(\mathrm{N}-\mathrm{H})$ vibrations or the presence of strong inter-/intramolecular hydrogen bonding in the solid state and the consequent perturbation of the $v(\mathrm{O}-\mathrm{H})$ and $\nu(\mathrm{N}-\mathrm{H})$ stretching vibrations. Infrared $\mathrm{NH}_{2}$ stretching frequencies were used to distinguish coordinated from non-coordinated amino groups of the ligand [1]. The position of $v(\mathrm{~N}-$ $\mathrm{H}$ ) bands is influenced by hydrogen bonding and by coordination of the nitrogen to tin [1]. In all of the studied 
TABLE 2: IR frequencies ${ }^{\mathrm{a}}$ (in $\mathrm{cm}^{-1}$ ) of di- and triorganotin(IV) tyrosylalaninates.

\begin{tabular}{|c|c|c|c|c|c|c|c|}
\hline Compound & $\nu(\mathrm{O}-\mathrm{H})$ & $\nu(\mathrm{N}-\mathrm{H}) / \nu(\mathrm{C}-\mathrm{H})$ & $\nu(\mathrm{CO})_{\text {amide }}$ & $\nu_{\mathrm{as}}(\mathrm{COO}) / \nu_{\mathrm{s}}(\mathrm{COO})$ & $\Delta v$ & $\nu_{\mathrm{as}}(\mathrm{Sn}-\mathrm{C}) / \nu_{\mathrm{s}}(\mathrm{Sn}-\mathrm{C})$ & $\nu(\mathrm{Sn}-\mathrm{O}) / \nu(\mathrm{Sn} \leftarrow \mathrm{N})$ \\
\hline $\mathrm{H}_{2}$ Tyr-Ala & & $\begin{array}{l}3440 \mathrm{~m} \\
3180 \mathrm{br}\end{array}$ & 1670 & $\begin{array}{l}1560 \mathrm{~m} \\
1390 \mathrm{~m}\end{array}$ & 170 & - & - \\
\hline $\mathrm{Me}_{2} \mathrm{Sn}(\mathrm{Tyr}-\mathrm{Ala})$ & $3516 \mathrm{~m}$ & $\begin{array}{l}3380 \mathrm{~m} \\
3286 \mathrm{~m} \\
3230 \mathrm{w} \\
3177 \mathrm{~m} \\
2924 \mathrm{w}\end{array}$ & 1594 vs & $\begin{array}{c}1514 \mathrm{~m} / 1340 \mathrm{w} \\
1291 \mathrm{w}\end{array}$ & 174 & $592 \mathrm{~m} / 523 \mathrm{~m}$ & $551 \mathrm{~m} / 489 \mathrm{w}$ \\
\hline$n-\mathrm{Bu}_{2} \mathrm{Sn}(\mathrm{Tyr}-\mathrm{Ala})$ & $3566 \mathrm{~m}$ & $\begin{array}{c}3427 \mathrm{~s} \\
3343 \mathrm{~s} \\
3239 \mathrm{w} \\
3187 \mathrm{~s}\end{array}$ & $1655 \mathrm{~s}$ & $1622 \mathrm{vs} / 1369 \mathrm{w}$ & 253 & $671 \mathrm{~m} / 587 \mathrm{~m}$ & $557 \mathrm{~m} / 451 \mathrm{~m}$ \\
\hline$n$-Oct 2 Sn (Tyr-Ala) & $3586 \mathrm{~m}$ & $\begin{array}{l}3412 \mathrm{~m} \\
3270 \mathrm{~m} \\
3227 \mathrm{~m} \\
3014 \mathrm{w}\end{array}$ & 1640 brsh & $1610 \mathrm{vs} / 1379 \mathrm{~m}$ & 231 & $677 \mathrm{~m} / 555 \mathrm{~s}$ & $570 \mathrm{w} / 452 \mathrm{vw}$ \\
\hline $\mathrm{Ph}_{2} \mathrm{Sn}($ Tyr-Ala $)$ & $3571 \mathrm{~s}$ & $\begin{array}{c}3424 \mathrm{~s} \\
3333 \mathrm{~s} \\
3231 \mathrm{w} \\
3194 \mathrm{~s}\end{array}$ & 1633 vs & $1615 \mathrm{~s} / 1397 \mathrm{~m}$ & 218 & $247 \mathrm{~m} / 226 \mathrm{~m}$ & $533 \mathrm{~m} / 457 \mathrm{~m}$ \\
\hline $\mathrm{Me}_{3} \mathrm{Sn}(\mathrm{HTyr}-\mathrm{Ala})$ & 3439 br & $\begin{array}{l}3332 s \\
3265 s \\
3101 s\end{array}$ & $1659 \mathrm{~m}$ & 1602 vs/1394 m & 208 & $607 \mathrm{w} / 591 \mathrm{w}$ & $545 \mathrm{~m} / 424 \mathrm{~m}$ \\
\hline $\mathrm{Ph}_{3} \mathrm{Sn}$ (HTyr-Ala) & $3457 \mathrm{~s}$ & $\begin{array}{l}3344 \mathrm{~s} \\
3171 \mathrm{~s} \\
3055 \mathrm{~s}\end{array}$ & 1660 vs & $1526 \mathrm{~s} / 1250 \mathrm{~s}$ & 276 & $280 \mathrm{~m} / 228 \mathrm{w}$ & $503 \mathrm{~m} / 449 \mathrm{~m}$ \\
\hline
\end{tabular}

av, very strong; s, strong; m, medium; w, weak; br, broad.

organotin(IV) tyrosylalaninates, some bands in region $3427-$ $3055 \mathrm{~cm}^{-1}$ undergo substantial lowering when compared with $\mathrm{H}_{2}$ Tyr-Ala $\left(3440-3180 \mathrm{~cm}^{-1}\right)$, indicating the participation of amino group in coordination to tin. It is supported by similar studies reported for other derivatives, $\mathrm{R}_{2} \mathrm{SnL}[1$, $12,14,25]$ and $\mathrm{R}_{3} \operatorname{SnHL}\left(\mathrm{H}_{2} \mathrm{~L}=\right.$ dipeptide $)[1,12,14,17-24]$, indicating coordination by the amino group to the central tin atom. The appearance of a new band of medium intensity in the region $\sim 489-424 \mathrm{~cm}^{-1}$ in all of the studied derivatives, which may be assigned to $\nu(\mathrm{Sn} \leftarrow \mathrm{N})$, further confirms the coordination of the amino nitrogen to the organotin(IV) moiety.

The carboxylate groups in the organotin(IV) derivatives generally adopt a bridged structure in the solid state unless the organic substituents at the tin atom are bulky or the carboxylate group is branched at the $\alpha$-carbon [1]. The $v_{\text {as }}\left(-\mathrm{C}(\mathrm{O}) \mathrm{O}^{-}\right)$is observed at $1560 \mathrm{~cm}^{-1}$ in $\mathrm{H}_{2}$ Tyr-Ala as found in most of the amino acids in their zwitterionic form. The IR spectra of the organotin(IV) tyrosylalaninates indicate that $v_{\text {as }}\left(-\mathrm{C}(\mathrm{O}) \mathrm{O}^{-}\right)$vibrations shift to higher wave number $\left(1622-1514 \mathrm{~cm}^{-1}\right)$ in comparison to $\mathrm{H}_{2}$ TyrAla $\left(1560 \mathrm{~cm}^{-1}\right)$. The corresponding $\nu_{\mathrm{s}}\left(-\mathrm{C}(\mathrm{O}) \mathrm{O}^{-}\right)$in the synthesized derivatives $\left(1397-1250 \mathrm{~cm}^{-1}\right)$ either remains at the same value or moves to lower wave number side than in $\mathrm{H}_{2}$ Tyr-Ala $\left(1390 \mathrm{~cm}^{-1}\right)$. The magnitude of the $\left[\nu_{\mathrm{as}}\left(-\mathrm{C}(\mathrm{O}) \mathrm{O}^{-}\right)-v_{\mathrm{as}}\left(-\mathrm{C}(\mathrm{O}) \mathrm{O}^{-}\right)\right](\Delta \nu)$ separation is large in studied organotin(IV) tyrosylalaninates $(\Delta \nu=208-$ $\left.276 \mathrm{~cm}^{-1}\right)$ than in $\mathrm{H}_{2}$ Tyr-Ala $\left(\Delta \nu=170 \mathrm{~cm}^{-1}\right)$. Further the magnitude of $\Delta \nu$ for all these derivatives have been found comparable to those obtained for $\mathrm{R}_{3} \mathrm{SnAA}(\mathrm{AA}=$ amino acid anion) $[1,7,9-12]$ and $\mathrm{R}_{2} \mathrm{SnL}\left(\mathrm{H}_{2} \mathrm{~L}=\right.$ dipeptide) $[1$, $12,14,17-24]$, indicating that the carboxylate group acts as a monodentate donor group in $\mathrm{H}_{2} \mathrm{Tyr}-\mathrm{Ala}$, and hence the possibility of ionic bonding and also bridging and chelation can be excluded $[1,12,14,17-24]$. The appearance of a new medium intensity band in the far-IR spectra of all the derivatives in the region $570-503 \mathrm{~cm}^{-1}$, which may be assigned to $v(\mathrm{Sn}-\mathrm{O})$, further supports the bonding of carboxylate group to the tin atom $[1,12,14,17-24]$.

Apart from the potential coordinating sites, namely, carboxylic oxygen and amino nitrogen, the amide group also exhibits strong tendency to coordinate with the organotin(IV) moiety. Two characteristic bands, namely, amide I (essentially $v(\mathrm{C}=\mathrm{O}))$ and amide II $[\delta(\mathrm{N}-\mathrm{H})$, coupled with $v(\mathrm{C}-\mathrm{N})]$, give the crucial information on the occurrence of metal coordination through the basic atoms of the amide group [17, 34]. Two intense bands observed at 1670 and $1450 \mathrm{~cm}^{-1}$ in the IR spectrum of $\mathrm{H}_{2}$ Tyr-Ala have been assigned to amide I and amide II, respectively. The amide I band undergoes a small shift towards lower frequency $\left(1655-1594 \mathrm{~cm}^{-1}\right)$ in the IR spectra of diorganotin(IV) tyrosylalaninates upon complexation. This is probably due to the involvement of the peptide nitrogen in bonding with tin, which lowers the bond order of the $(\mathrm{C}=\mathrm{O})_{\text {amide }}$ group due to the resonance stabilization [18]. The amide II band is absent in all of the diorganotin(IV) tyrosylalaninates due to the deprotonation of the amide nitrogen. In the IR spectra of $\mathrm{Me}_{3} \mathrm{Sn}$ (HTyr-Ala) and $\mathrm{Ph}_{3} \mathrm{Sn}$ (HTyr-Ala), amide 
TABLE 3: ${ }^{119} \mathrm{Sn}$ Mössbauer spectral data $(80 \mathrm{~K})$ of di- and triorganotin(IV) tyrosylalaninates ${ }^{\mathrm{a}}$.

\begin{tabular}{|c|c|c|c|c|c|c|}
\hline Compound no. & QS $\left(\mathrm{mm} \mathrm{s}^{-1}\right)$ & IS $\left(\mathrm{mm} \mathrm{s}^{-1}\right)$ & $\rho(\mathrm{QS} / \mathrm{IS})$ & $\tau_{1}(\mathrm{~L})$ & $\tau_{2}(\mathrm{R})$ & $\angle \mathrm{C}-\mathrm{Sn}-\mathrm{C}^{\mathrm{b}}\left({ }^{\circ}\right)$ \\
\hline $\mathrm{Me}_{2} \mathrm{Sn}(\mathrm{Tyr}-\mathrm{Ala})$ & 3.28 & 1.23 & 2.67 & 1.09 & 1.42 & 135.67 \\
\hline$n-\mathrm{Bu}_{2} \mathrm{Sn}(\mathrm{Tyr}-\mathrm{Ala})$ & 2.58 & 1.11 & 2.32 & 1.31 & 1.59 & 115.81 \\
\hline$n-\mathrm{Oct}_{2} \mathrm{Sn}(\mathrm{Tyr}-\mathrm{Ala})$ & 3.41 & 1.39 & 2.45 & 0.97 & 1.07 & 131.62 \\
\hline $\mathrm{Ph}_{2} \mathrm{Sn}$ (Tyr-Ala) & 2.35 & 0.91 & 2.58 & 1.27 & 2.0 & 114.85 \\
\hline $\mathrm{Me}_{3} \mathrm{Sn}(\mathrm{HTyr}-\mathrm{Ala})$ & 3.32 & 1.26 & 2.63 & 1.0 & 1.22 & 136.86 \\
\hline $\mathrm{Ph}_{3} \mathrm{Sn}$ (HTyr-Ala) & 2.13 & 0.97 & 2.20 & 1.08 & 1.20 & 107.01 \\
\hline
\end{tabular}

${ }^{a}$ QS: quadruple splitting; IS: isomer shift relative to $\mathrm{BaSnO}_{3}$ and tin foil (splitting: $2.52 \mathrm{~mm} \mathrm{~s}^{-1}$ ); $\tau_{1}$ (L): half line-width left doublet component; $\tau_{2}$ (R): half line-width right doublet component.

${ }^{b}$ Parish's relationship [35]: QS $=4[\mathrm{R}]\left[1-(3 / 4) \sin ^{2} 2 \theta\right]^{1 / 2}$, where $\angle \mathrm{C}-\mathrm{Sn}-\mathrm{C}=(180-2 \theta)^{\circ}$ and $[\mathrm{R}]$ is the partial quadruple splitting (p.q.s.). For alkyl and phenyl groups, $\mathrm{R}=-1.03$ and $-0.95 \mathrm{mms}^{-1}$, respectively $[35,44]$.
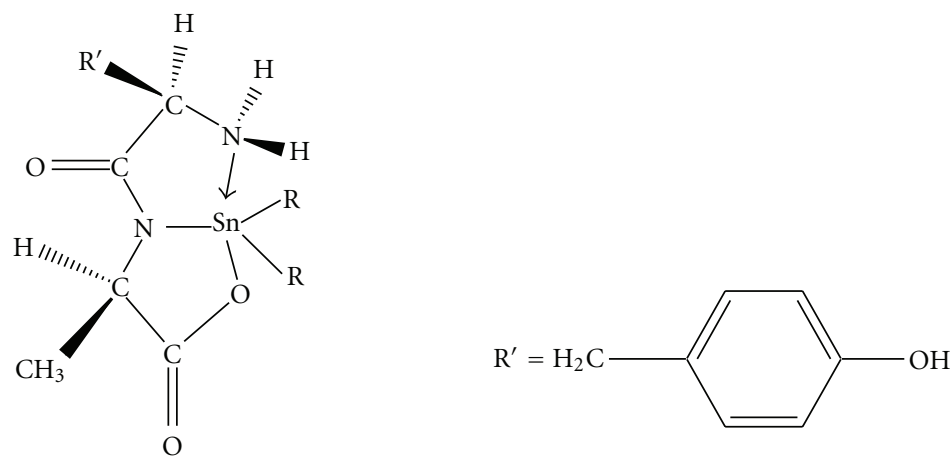

$\mathrm{R}=\mathrm{Me}, n-\mathrm{Bu}, n$-Oct and $\mathrm{Ph}$

Figure 1: Structure of diorganotin(IV) tyrosinylalaninates.

I band undergoes a very small shift to lower wave number $\sim 1660 \mathrm{~cm}^{-1}$ as compared to $\mathrm{H}_{2} \mathrm{Tyr}-\mathrm{Ala}\left(1670 \mathrm{~cm}^{-1}\right)$, indicating that the amide group does not take part in coordination to tin. The participation of amide group in coordination would have been followed by a significant shift in position of amide I band. However, the small shift of this band either may be due to the shifting of $\delta(\mathrm{N}-\mathrm{H})_{\text {def }}$ which is caused by the coordination of $\mathrm{NH}_{2}$ to tin or their participation in the intermolecular hydrogen bonding, as reported previously for $\mathrm{R}_{3} \mathrm{Sn}(\mathrm{HL})\left(\mathrm{H}_{2} \mathrm{~L}=\right.$ dipeptide $)$ derivatives $[12,19]$.

The $v_{\text {as }}(\mathrm{Sn}-\mathrm{C})$ and $v_{\mathrm{s}}(\mathrm{Sn}-\mathrm{C})$ bands in all of the di- and trialkyltin(IV) tyrosylalaninates are observed in the range $634 \pm 43 \mathrm{~cm}^{-1}$, whereas in the di- and triphenyltin(IV) tyrosylalaninates, the corresponding $\nu_{\text {as }}(\mathrm{Sn}-\mathrm{C})$ and $\nu_{\mathrm{s}}(\mathrm{Sn}-\mathrm{C})$ are observed at $230 \pm 17 \mathrm{~cm}^{-1}$ and $227 \pm 1 \mathrm{~cm}^{-1}$, respectively, suggesting the existence of a bent C-Sn-C moiety $[1,7]$.

3.2. ${ }^{119} \mathrm{Sn}$ Mössbauer Spectroscopy. The experimental nuclear quadrupole splitting (QS) and isomeric shift (IS) values of the studied di- and triorganotin(IV) tyrosylalaninates in the solid state are presented in Table 3. The $\rho$ (QS/IS) value is $>2$ which indicates a coordination number more than 4 in the solid state for these derivatives. The observed low value of QS for di- and triphenyltin(IV) tyrosylalaninates is due to greater polarizability of the phenyl groups.

The IS and QS values observed for $\mathrm{R}_{2} \mathrm{Sn}$ (Tyr-Ala) (see Table 3) are consistent with the other $\mathrm{R}_{2} \mathrm{SnL}$ derivatives (where $\mathrm{H}_{2} \mathrm{~L}=$ dipeptides) $[1,12,14,17]$. For which a distorted trigonal-bipyramidal configuration has been reported with the organic groups of the organotin(IV) moiety, and peptide nitrogen is lying in equatorial position, and the amino nitrogen and carboxylic oxygen atoms are axial $[1,12,14,17]$. Due to the high electronegativity of oxygen and nitrogen atom of the dipeptide anion, the QS is mainly governed by $\angle \mathrm{C}-\mathrm{Sn}-\mathrm{C}$ bond angle [35]. The calculated values of $\angle \mathrm{C}-\mathrm{Sn}-\mathrm{C}$ in the studied diorganotin(IV) tyrosylalaninates are in the range $\sim 115-136^{\circ}$ (Table 3 ). Thus, the tin atom configuration as shown in Figure 1 can be proposed for $\mathrm{R}_{2} \mathrm{Sn}$ (Tyr-Ala), on the basis of the abovementioned similarity between the observed and reported QS values $[12,14,17]$ and the calculated $\angle \mathrm{C}-\mathrm{Sn}-\mathrm{C}$ values.

The Mössbauer spectra of the $\mathrm{R}_{3} \mathrm{Sn}$ (HTyr-Ala) (where $\mathrm{R}=\mathrm{Me}, \mathrm{Ph})$ derivatives exhibit a doublet centered in the IS value range $0.97-1.26 \mathrm{~mm} \mathrm{~s}^{-1}$ and the quadrupole splitting (QS) values in the range $2.13-3.32 \mathrm{~mm} \mathrm{~s}^{-1}$. It has been reported [36] that the three conceivable (Figure 2) five-coordinate isomers of $\mathrm{R}_{3} \mathrm{SnL}$ derivatives, where $\mathrm{L}$ is a bidentate ligand, have different QS values ranges, 1.7$2.3 \mathrm{~mm} \mathrm{~s}^{-1}$ for isomer (a), $3.0-3.9 \mathrm{~mm} \mathrm{~s}^{-1}$ for (b), and $3.5-4.1 \mathrm{~mm} \mathrm{~s}^{-1}$ for (c). The observed values of IS and QS for $\mathrm{Me}_{3} \mathrm{Sn}$ (HTyr-Ala) and $\mathrm{Ph}_{3} \mathrm{Sn}$ (HTyr-Ala), support trans-trigonal-bipyramidal coordination (Figure 2(b)) and cis-trigonal-bipyramidal coordination (Figure 2(a)) of tin, respectively. Therefore, the structures as shown in Figure 3 


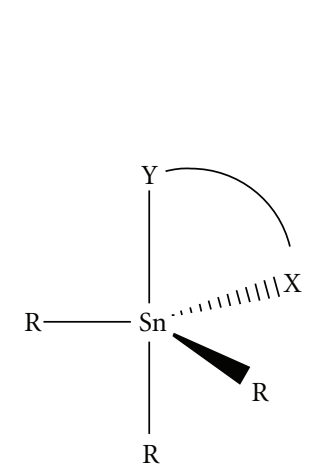

(a)

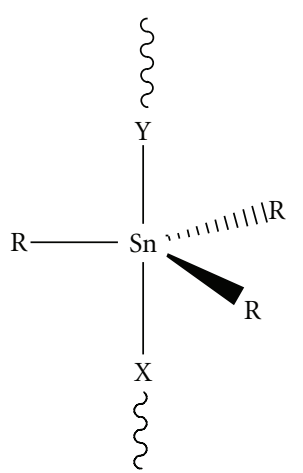

(b)

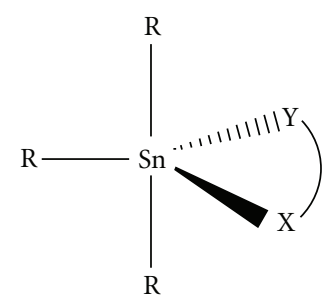

(c)

Figure 2: Three possible isomers of $\mathrm{R}_{3} \mathrm{Sn}(\mathrm{XY})$ [36].

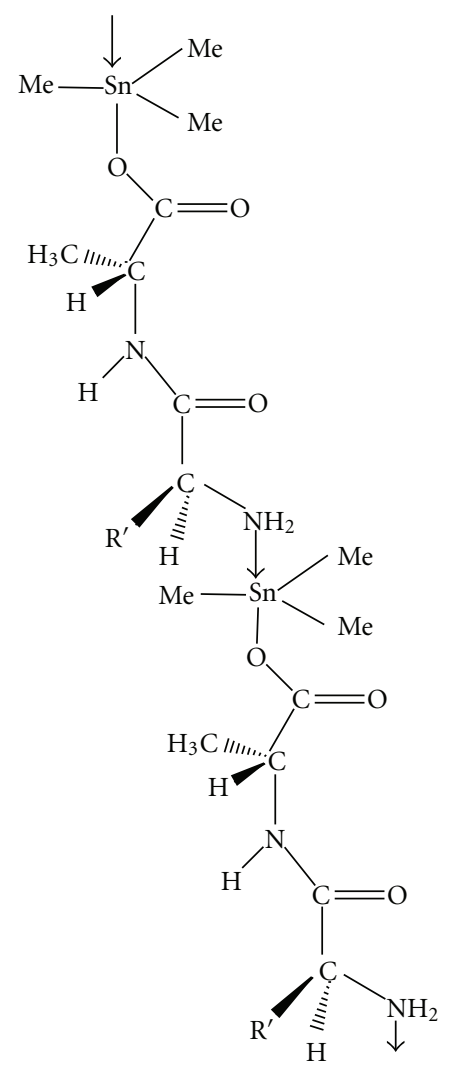

(a)<smiles>[Y][C@H]1N[N+](c2ccccc2)(c2ccccc2)[C@H](O)[C@@H](C)NC1=O</smiles>

(b)

FIgUre 3: Proposed structure of (a) trimethyltin(IV) tyrosinylalaninate and (b) triphenyltin(IV) tyrosinylalaninate.

have been proposed for trimethyl-/triphenyltin(IV) tyrosylalaninates, which are also supported by the calculated values of $\angle \mathrm{C}-\mathrm{Sn}-\mathrm{C}$ of $\sim 137^{\circ}$ for trimethyl- and $\sim 107.01^{\circ}$ for triphenyltin(IV) derivatives (Table 3). Similar structures have also been reported for $\mathrm{Me}_{3} \mathrm{Sn}(\mathrm{HL})[19,20]$ and $\mathrm{Ph}_{3} \mathrm{Sn}(\mathrm{HL})[12,17,20]$ (where $\mathrm{H}_{2} \mathrm{~L}=$ dipeptide).

Further, the Mössbauer data (Table 3) indicate a pronounced line intensity asymmetry (the Goldanskii-Karyagin effect) in all of the studied organotin(IV) derivatives, which reflects a lattice dynamic anisotropy in the recoil-free fraction arising in the organotin(IV) derivatives possessing intermolecular association along particular axis in the solid state [37]. Further, the intermolecular hydrogen bonding between amino and carbonyl oxygen is also present to some extent in all of these studied derivatives, which is responsible for the low solubility of these derivatives in common organic solvents.

3.3. Solution NMR Spectroscopy. The characteristic resonances in the ${ }^{1} \mathrm{H},{ }^{13} \mathrm{C}$, and ${ }^{119} \mathrm{Sn}$ NMR spectra of $\mathrm{H}_{2}$ TyrAla [38] and its organotin(IV) derivatives, recorded in methanol- $\mathrm{d}_{4}$, are presented in Tables 4,5 , and 6 . In the ${ }^{1} \mathrm{H}$ 
TABLe 4: ${ }^{1} \mathrm{H}$ NMR spectral data of $\mathrm{H}_{2}$ Tyr-Ala (recorded in $\mathrm{D}_{2} \mathrm{O}$ ) [38] and of di- and triorganotin(IV) tyrosylalaninates ${ }^{\mathrm{a}}$ (recorded in $\left.\mathrm{CD}_{3} \mathrm{OD}\right)$.

\begin{tabular}{|c|c|}
\hline Compound & $\delta(\mathrm{ppm})$ \\
\hline $\mathrm{H}_{2}$ Tyr-Ala & $\begin{array}{l}3.78(\mathrm{q}, 1 \mathrm{H}, 7.25 \mathrm{~Hz}, \mathrm{H}-2) ; 1.49(\mathrm{~d}, 3 \mathrm{H}, 7.5 \mathrm{~Hz}, \mathrm{H}-3) ; 3.93(\mathrm{dd}, 1 \mathrm{H}, 5.7,8.2 \mathrm{~Hz}, \mathrm{H}-6) ; 3.17^{\mathrm{b}}(\mathrm{d}, 2 \mathrm{H}, \mathrm{H}-7) ; 7.19 \\
(\mathrm{~d}, 2 \mathrm{H}, 8.9 \mathrm{~Hz}, \mathrm{H}-9,13) ; 6.88(\mathrm{~d}, 2 \mathrm{H}, \mathrm{H}-10,12) .\end{array}$ \\
\hline $\mathrm{Me}_{2} \mathrm{Sn}(\mathrm{Tyr}-\mathrm{Ala})$ & $\begin{array}{l}4.19(\mathrm{q}, 1 \mathrm{H}, 6.6 \mathrm{~Hz}, \mathrm{H}-2) ; 1.37 /(1.33)(\mathrm{d}, 3 \mathrm{H}, 6.9 \mathrm{~Hz}, \mathrm{H}-3) ; 3.74(\mathrm{dd}, 1 \mathrm{H}, 4.5,4.8 \mathrm{~Hz}, \mathrm{H}-6) ; 3.16-2.73^{\mathrm{b}}(\mathrm{m}, 2 \mathrm{H}, \\
\mathrm{H}-7) ; 7.08 /(7.05)(\mathrm{d}, 2 \mathrm{H}, 8.4 \mathrm{~Hz}, \mathrm{H}-9,13) ; 6.75(\mathrm{~d}, 2 \mathrm{H}, 6.3 \mathrm{~Hz}, \mathrm{H}-10,12) ; 0.69 /(0.50)(\mathrm{s}, 6 \mathrm{H}, \mathrm{H}-\alpha)\left[{ }^{2} \mathrm{~J}\left({ }^{1} \mathrm{H}-{ }^{119} \mathrm{Sn}\right)=\right. \\
76.8 / 77.4 \mathrm{~Hz}] . \angle \mathrm{Me}-\mathrm{Sn}-\mathrm{Me}^{\mathrm{c}}=126.99 / 127.68^{\circ} .\end{array}$ \\
\hline$n-\mathrm{Bu}_{2} \mathrm{Sn}(\mathrm{Tyr}-\mathrm{Ala})$ & $\begin{array}{l}4.20^{\mathrm{b}}(\mathrm{m}, 1 \mathrm{H}, \mathrm{H}-2) ; 1.73-1.01^{\mathrm{b}}(\mathrm{m}, 15 \mathrm{H}, \mathrm{H}-3, \mathrm{H}-\alpha, \mathrm{H}-\beta \text { and } \mathrm{H}-\gamma) ; 3.70(\mathrm{t}, 1 \mathrm{H}, 5.4 \mathrm{~Hz}, \mathrm{H}-6) / 3.51(\mathrm{dd}, 1 \mathrm{H}, 4.5 \mathrm{~Hz}, \\
\mathrm{H}-6) ; 3.19-2.64^{\mathrm{b}}(\mathrm{mbr}, 2 \mathrm{H}, \mathrm{H}-7) ; 7.03(\mathrm{~d}, 2 \mathrm{H}, 8.1 \mathrm{~Hz}, \mathrm{H}-9,13) ; 6.71(\mathrm{br}, 2 \mathrm{H}, \mathrm{H}-10,12) ; 0.90(\mathrm{t}, 6 \mathrm{H}, 7.2 \mathrm{~Hz}, \mathrm{H}-\delta) .\end{array}$ \\
\hline$n$-Oct 2 Sn (Tyr-Ala) & $\begin{array}{l}4.19(\mathrm{q}, 1 \mathrm{H}, 6.9 \mathrm{~Hz}, \mathrm{H}-2) ; 1.58-0.87^{\mathrm{b}}\left(\mathrm{m}, 37 \mathrm{H}, \mathrm{H}-3 \text { and } \mathrm{CH}_{2} \mathrm{CH}_{2} \mathrm{CH}_{2} \mathrm{CH}_{2} \mathrm{CH}_{2} \mathrm{CH}_{2} \mathrm{CH}_{2} \mathrm{CH}_{3}\right) ; 3.69(\mathrm{t}, 1 \mathrm{H}, 5.4 \mathrm{~Hz}, \\
\mathrm{H}-6) ; 3.18-3.01^{\mathrm{b}}(\mathrm{m}, 2 \mathrm{H}, \mathrm{H}-7) ; 7.08(\mathrm{~d}, 2 \mathrm{H}, 8.4 \mathrm{~Hz}, \mathrm{H}-9,13) ; 6.77(\mathrm{~d}, 2 \mathrm{H}, 8.1 \mathrm{~Hz}, \mathrm{H}-10,12) .\end{array}$ \\
\hline $\mathrm{Ph}_{2} \mathrm{Sn}$ (Tyr-Ala) & $\begin{array}{l}4.37 /(4.21)(\mathrm{q}, 1 \mathrm{H}, 6.9 \mathrm{~Hz}, \mathrm{H}-2) ; 1.44 /(1.32)(\mathrm{d}, 3 \mathrm{H}, 6.9 \mathrm{~Hz}, \mathrm{H}-3) ; 3.79 / 3.53(\mathrm{t}, 1 \mathrm{H}, 5.4 \mathrm{~Hz}, \mathrm{H}-6) ; 3.19-2.66^{\mathrm{b}} \\
(\mathrm{m}, 2 \mathrm{H}, \mathrm{H}-7) ; 7.03(\mathrm{dd}, 2 \mathrm{H}, 9.0 \mathrm{~Hz}, \mathrm{H}-9,13) ; 6.72(\mathrm{~d}, 2 \mathrm{H}, 7.2 \mathrm{~Hz}, \mathrm{H}-10,12) ; 7.79(\mathrm{~d}, 4 \mathrm{H}, 6.3 \mathrm{~Hz}, \mathrm{H}-\mathrm{o})\left[{ }^{3} \mathrm{~J}\left({ }^{1} \mathrm{H}-\right.\right. \\
\left.\left.{ }_{119 / 117} \mathrm{Sn}\right)=67 / 52 \mathrm{~Hz}\right] ; 7.46(\mathrm{~m}, 6 \mathrm{H}, \mathrm{H}-\mathrm{m}+\mathrm{p}) .\end{array}$ \\
\hline $\mathrm{Me}_{3} \mathrm{Sn}(\mathrm{HTyr}-\mathrm{Ala})$ & $\begin{array}{l}4.21(\mathrm{q}, 1 \mathrm{H}, 6.0 \mathrm{~Hz}, \mathrm{H}-2) ; 1.32(\mathrm{~d}, 3 \mathrm{H}, 6.0 \mathrm{~Hz}, \mathrm{H}-3) ; 3.63(\mathrm{t}, 1 \mathrm{H}, 6.0 \mathrm{~Hz}, \mathrm{H}-6) ; 3.01(\mathrm{dd}, 2 \mathrm{H}, 6.0 \mathrm{~Hz}, \mathrm{H}-7) / 2.74 \\
(\mathrm{dd}, 2 \mathrm{H}, 9.0 \mathrm{~Hz}, \mathrm{H}-7) ; 7.06(\mathrm{~d}, 2 \mathrm{H}, 8.1 \mathrm{~Hz}, \mathrm{H}-9,13) ; 6.72(\mathrm{~d}, 2 \mathrm{H}, 8.4 \mathrm{~Hz}, \mathrm{H}-10,12) ; 0.47(\mathrm{~s}, 9 \mathrm{H}, \mathrm{H}-\alpha)\left[{ }^{2} \mathrm{~J}\left({ }^{1} \mathrm{H}-\right.\right. \\
\left.\left.{ }^{119} \mathrm{Sn}\right)=66 \mathrm{~Hz}\right] . \angle \mathrm{Me}-\mathrm{Sn}-\mathrm{Me}^{\mathrm{c}}=116.41^{\circ} \text {. }\end{array}$ \\
\hline $\mathrm{Ph}_{3} \mathrm{Sn}(\mathrm{HTyr}-\mathrm{Ala})$ & $\begin{array}{l}4.22(\mathrm{q}, 1 \mathrm{H}, 7.2 \mathrm{~Hz}, \mathrm{H}-2) ; 1.27(\mathrm{~d}, 3 \mathrm{H}, 7.2 \mathrm{~Hz}, \mathrm{H}-3) ; 3.60(\mathrm{dd}, 1 \mathrm{H}, 2.7 \mathrm{~Hz}, \mathrm{H}-6) ; 2.97(\mathrm{dd}, 2 \mathrm{H}, 4.5 \mathrm{~Hz}, \mathrm{H}- \\
7) / 2.67(\mathrm{dd}, 2 \mathrm{H}, 8.4 \mathrm{~Hz}, \mathrm{H}-7) ; 7.01(\mathrm{~d}, 2 \mathrm{H}, 7.8 \mathrm{~Hz}, \mathrm{H}-9,13) ; 6.71(\mathrm{~d}, 2 \mathrm{H}, 8.4 \mathrm{~Hz}, \mathrm{H}-10,12) ; 7.80(\mathrm{~d}, 6 \mathrm{H}, 6.0 \mathrm{~Hz} \text {, } \\
\mathrm{H}-\beta)\left[{ }^{3} \mathrm{~J}\left({ }^{1} \mathrm{H}-1{ }^{19 / 117} \mathrm{Sn}\right)=68 / 56 \mathrm{~Hz}\right] ; 7.48-7.41(\mathrm{~m}, 6 \mathrm{H}, \mathrm{H}-\gamma, \mathrm{H}-\delta)^{\mathrm{b}} .\end{array}$ \\
\hline
\end{tabular}

as, singlet; d: doublet; dd: double doublet; t: triplet; q: quartet; m: multiplet; br: broad; weak or nonprominent signals are written in parenthesis. ${ }^{\text {b Strongly }}$ overlapping multiplets ${ }^{\mathrm{c}} \angle \mathrm{Me}-\mathrm{Sn}-\mathrm{Me}=\left.\left.0.0161\right|^{2} \mathrm{~J}\right|^{2}-\left.1.32\right|^{2} \mathrm{~J} \mid+133.4$; the Lockhart and Manders equation [39].

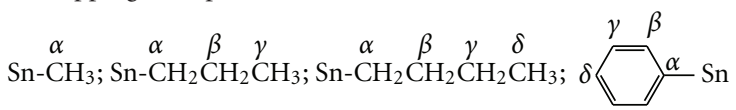

NMR spectra of all of the derivatives studied, the $-\mathrm{CO}(\mathrm{OH})$ resonance of $\mathrm{H}_{2}$ Tyr-Ala $(\delta 12.0-13.0 \mathrm{ppm})$ is absent which suggests the replacement of the carboxylic proton by the organotin(IV) moiety. In $1 \mathrm{H}$ NMR spectra of $\mathrm{H}_{2}$ Tyr-Ala and its organotin(IV) derivatives, it is difficult to assign $\mathrm{NH}_{2}$ resonance with certainty because it is observed either as a broad weak signal or in conjugation with phenyl protons attached to the ligand or tin. The resonances due to magnetically nonequivalent alkyl/phenyl protons and carbons of $\mathrm{H}_{2} \mathrm{Tyr}-$ Ala undergo diamagnetic shielding due to the conformation adopted by the ligand molecule $[1,12,14]$ on coordination. The assignments of carbon and protons are also supported by the ${ }^{1} \mathrm{H}-{ }^{13} \mathrm{C} \mathrm{HMBC}$ and ${ }^{1} \mathrm{H}-{ }^{13} \mathrm{C}$ HSQC spectra of $\mathrm{Ph}_{2} \mathrm{Sn}$ (TyrAla). The total numbers of protons calculated from the integration curve are in agreement with those calculated from the proposed molecular formula. In the ${ }^{13} \mathrm{C}$ NMR spectra, the resonance of carboxylic carbon (i.e., C-1) in all of the studied organotin(IV) tyrosinylalaninates shows a downward shift ( $\delta$ 178.9-181.4 ppm) as compared to $\mathrm{H}_{2}$ TyrAla $(\delta 176.2 \mathrm{ppm})$ suggesting the coordination of $\mathrm{H}_{2}$ TyrAla through the carboxylic oxygen to the organotin(IV) moiety $[1,12,14,17,19]$. The ${ }^{2} \mathrm{~J}\left({ }^{1} \mathrm{H}-{ }^{117 / 119} \mathrm{Sn}\right)$ coupling constant values obtained from the resolved satellites for $\mathrm{Me}_{2} \mathrm{Sn}(\mathrm{IV})$ and $\mathrm{Me}_{3} \mathrm{Sn}(\mathrm{IV})$ tyrosinylalaninates are 76.8/77.4 and $66.0 \mathrm{~Hz}$, respectively. The $\angle \mathrm{Me}-\mathrm{Sn}-\mathrm{Me}$ angle calculated by using the Lockhart and Manders equation [39] are $126.99 / 127.68^{\circ}$ and $116.41^{\circ}$, respectively. Further, for $\mathrm{Me}_{3} \mathrm{Sn}(\mathrm{IV})$ tyrosylalaninate, the observed ${ }^{1} \mathrm{~J}\left({ }^{13} \mathrm{C}-{ }^{117 / 119} \mathrm{Sn}\right)$ coupling constant and calculated $\angle \mathrm{Me}-\mathrm{Sn}-\mathrm{Me}$ are $450.0 \mathrm{~Hz}$ and $116.23^{\circ}$, respectively. The calculated $\angle \mathrm{Me}-\mathrm{Sn}-\mathrm{Me}$ angle for $\mathrm{Me}_{2} \mathrm{Sn}(\mathrm{IV})$ and $\mathrm{Me}_{3} \mathrm{Sn}(\mathrm{IV})$ tyrosinylalaninates using NMR data is different from the angle calculated using ${ }^{119} \mathrm{Sn}$ Mössbauer data (Table 3) in the solid state which may be due to solvent effect, and suggesting five-coordinated tin in these derivatives in solution. For other studied organotin(IV) tyrosinylalaninates, the satellites are not well resolved; hence, ${ }^{1} \mathrm{~J}$ and ${ }^{2} \mathrm{~J}$ coupling constants and C-Sn-C angle could not be calculated. Except $\mathrm{Me}_{3} \mathrm{Sn}$ (HTyr-Ala), two sets of resonances have been observed in most of the studied organotin(IV) tyrosinylalaninates in both ${ }^{1} \mathrm{H}$ and ${ }^{13} \mathrm{C}$ NMR spectra, which may be due to the presence of stereoisomers. In case of $\mathrm{Me}_{2} \mathrm{Sn}$ (Tyr-Ala), two resonances at $\delta 0.69$ and $0.50 \mathrm{ppm}$ in ${ }^{1} \mathrm{H}$ NMR and at $\delta 0.12$ and 0.03 in ${ }^{13} \mathrm{C}$ NMR spectra are clearly observed for $\mathrm{Me}_{2} \mathrm{Sn}$ moiety, which confirms the presence of two isomeric forms. However, in case of other studied organotin(IV) derivatives, it is not identified because of strongly overlapping pattern of alkyl and phenyl protons attached to tin.

The ${ }^{119} \mathrm{Sn}$ chemical shifts observed for alkyl- and phenyltin(IV) tyrosinylalaninates are given in Table 6. The tin shielding in the ${ }^{119} \mathrm{Sn}$ NMR spectra increases markedly with increase in coordination number from $\delta 200$ to -60 , -90 to -190 and -210 to $-400 \mathrm{ppm}$ associated with four-, five-, and six-coordinated alkyltin(IV) compounds, and these tin shifts are higher with phenyl compared to alkyl substituents [40]. The observed ${ }^{119} \mathrm{Sn}$ chemical shifts are in the range of $\delta-184.50$ to $-480.54 \mathrm{ppm}$, which are characteristic of the five- or six-coordinated tin. The ${ }^{119} \mathrm{Sn}$ NMR is more sensitive to structural changes as compared to ${ }^{1} \mathrm{H}$ and ${ }^{13} \mathrm{C}$ NMR. The observed ${ }^{119} \mathrm{Sn}$ shifts of these 
TABLE 5: ${ }^{13} \mathrm{C}$ NMR spectral data of $\mathrm{H}_{2}$ Tyr-Ala (recorded in $\mathrm{D}_{2} \mathrm{O}$ ) [38] and of di- and triorganotin(IV) tyrosylalaninates ${ }^{\mathrm{a}}$ (recorded in $\left.\mathrm{CD}_{3} \mathrm{OD}\right)$.

\begin{tabular}{|c|c|}
\hline Compound & $\delta(\mathrm{ppm})^{\mathrm{b}}$ \\
\hline $\mathrm{H}_{2}$ Tyr-Ala & $\begin{array}{l}\text { C-1: } 176.2 ; \text { C-2: 51.5; C-3: 17.2; C-5: } 175 . \\
156.3 .\end{array}$ \\
\hline $\mathrm{Me}_{2} \mathrm{Sn}(\mathrm{Tyr}-\mathrm{Ala})$ & $\begin{array}{l}\text { C-1: } 181.1,179.8 ; \text { C-2: 53.3, 51.6; C-3: } 19 . \\
\text { 131.4; C-9,13: 126.9, 129.1; C-10,12: } 117.2\end{array}$ \\
\hline$n-\mathrm{Bu}_{2} \mathrm{Sn}(\mathrm{Tyr}-\mathrm{Ala})$ & $\begin{array}{l}\text { C-1: } 181.4,179.8 ; C-2: 53.53,51.76 ; C-3: 19 \\
131.9,131.4 ; C-9,13: 125.3,128.5 ; C-10,12 \\
27.61 ; C-\delta: 13.92 .\end{array}$ \\
\hline$n$-Oct 2 Sn (Tyr-Ala) & $\begin{array}{l}\text { C-1: } 181.2 ; \text { C-2: } 53.5 ; \text { C-3: } 19.7 ; \text { C-5: } 175.4 \\
\text { 158.1; C-octyl group: } 34.73,34.58,32.99,3\end{array}$ \\
\hline $\mathrm{Ph}_{2} \mathrm{Sn}(\mathrm{Tyr}-\mathrm{Ala})$ & $\begin{array}{l}\text { C-1: } 180.9,179.6 ; \text { C-2: 53.32, 51.59; C-3: } \\
\text { 8: 131.9, 131.5; C-9,13: 129.7, 129.3; C-10 } \\
90 \mathrm{~Hz}] ; \text { C- } \gamma: 126.9 ; \text { C- } \delta: 130.6,130.4,130 .\end{array}$ \\
\hline $\mathrm{Me}_{3} \mathrm{Sn}(\mathrm{HTyr}-\mathrm{Ala})$ & $\begin{array}{l}\mathrm{C}-1: 179.1 ; \mathrm{C}-2: 51.1 ; \mathrm{C}-3: 18.9 ; \mathrm{C}-5: 174.5 \\
157.7 ; \mathrm{C}-\alpha:-2.0\left[{ }^{1} \mathrm{~J}\left({ }^{13} \mathrm{C}-{ }^{119 / 117} \mathrm{Sn}\right)=450 \mathrm{H}\right.\end{array}$ \\
\hline $\mathrm{Ph}_{3} \mathrm{Sn}(\mathrm{HTyr}-\mathrm{Ala})$ & $\begin{array}{l}\text { C-1: 178.9; C-2: } 51.2 \text { (51.7); C-3: } 19.0 \text { (20. } \\
\text { 9,13: 128.5; C-10,12: 116.6; C-11: nb; C- } \alpha \text { : } \\
\text { 135 Hz]; C- } \delta: 130.5 \text {. }\end{array}$ \\
\hline \multirow{2}{*}{\multicolumn{2}{|c|}{$\begin{array}{l}\text { a Spectrum recorded on the Bruker DRX } 300 \mathrm{MHz} \text {, FTNMR spectrometer. }{ }^{\mathrm{b}} \mathrm{We} \\
\text { by the Lockhart and Manders equation }[39] ;\left|{ }^{1} \mathrm{~J}\right|=11.4 \theta-875 .\end{array}$}} \\
\hline & \\
\hline \multicolumn{2}{|c|}{$\begin{array}{l}\text { TABLE 6: }{ }^{119} \text { Sn NMR spectral data of organotin(IV) derivatives of } \\
\mathrm{H}_{2} \text { Tyr-Ala (recorded in } \mathrm{CD}_{3} \mathrm{OD} \text { ). }\end{array}$} \\
\hline Compound & $\delta(\mathrm{ppm})$ \\
\hline $\mathrm{Me}_{2} \mathrm{Sn}(\mathrm{Tyr}-\mathrm{Ala})$ & -329.06 \\
\hline$n-\mathrm{Bu}_{2} \mathrm{Sn}(\mathrm{Tyr}-\mathrm{Ala})$ & -261.18 \\
\hline$n-\mathrm{Oct}_{2} \mathrm{Sn}(\mathrm{Tyr}-\mathrm{Ala})$ & -358.73 \\
\hline $\mathrm{Ph}_{2} \mathrm{Sn}$ (Tyr-Ala) & -480.54 \\
\hline $\mathrm{Me}_{3} \mathrm{Sn}(\mathrm{HTyr}-\mathrm{Ala})$ & -184.50 \\
\hline $\mathrm{Ph}_{3} \mathrm{Sn}(\mathrm{HTyr}-\mathrm{Ala})$ & -400.57 \\
\hline
\end{tabular}

compounds suggest that the nature of the solvent plays an important role in these compounds, and it is proposed that one molecule of $\mathrm{CD}_{3} \mathrm{OD}$ is coordinated to tin in these compounds in solution.

3.4. Potentiometric Studies in Aqueous Medium. Stability constants for the protonation of the dipeptide ligands, namely, tyrosylalanine $\left(\mathrm{H}_{2}\right.$ Tyr-Ala), glycyltyrosine $\left(\mathrm{H}_{2} \mathrm{Gly}-\right.$ Tyr $)$, and glycylisoleucine $\left(\mathrm{H}_{2}\right.$ Gly-Ile), and the formation constant of the complex species calculated from the $\mathrm{pH}$ metric titrations together with some derived data are given in Table 7. Some representative species distribution diagrams are depicted in Figures 4(a) and 4(b). The hydrolysis constants of dimethyltin(IV) and trimethyltin(IV) cations reported earlier $[33,41]$ have been taken into consideration during the evaluation of the $\mathrm{pH}$-metric data. The composition and solution speciation of these species are very close to these reported earlier for the dimethyltin(IV)-Gly-Gly [42] and dimethyltin(IV)-Ala-Gly [43].
3.4.1. Dimethyltin(IV)-Dipeptide Systems. Since the dipeptides used in the present study have the same set of coordinating atoms, hence the same species have been considered for all the binary dimethyltin(IV) systems namely, $\left[\mathrm{SnMe}_{2}(\mathrm{HL})\right]^{+},\left[\mathrm{SnMe}_{2} \mathrm{~L}\right],\left[\mathrm{SnMe}_{2} \mathrm{~L}(\mathrm{OH})\right]^{-},\left[\operatorname{SnMe}_{2}(\mathrm{OH})\right]^{+}$, $\left[\mathrm{SnMe}_{2}(\mathrm{OH})_{2}\right],\left[\mathrm{SnMe}_{2}(\mathrm{OH})_{3}\right]^{-},\left[\mathrm{SnMe}_{2} \mathrm{~L}(\mathrm{OH})_{2}\right]^{2-},\left[\mathrm{SnMe}_{2} \mathrm{~L}_{2}\right]^{2-}$, $\left[\mathrm{SnMe}_{2} \mathrm{~L}_{2}(\mathrm{OH})\right]^{3-}$, and $\left[\mathrm{SnMe}_{2} \mathrm{~L}_{2}(\mathrm{OH})_{2}\right]^{4-}$ (where $\mathrm{H}_{2} \mathrm{~L}$ $=\mathrm{H}_{2}$ Tyr-Ala, $\mathrm{H}_{2}$ Gly-Tyr and $\mathrm{H}_{2}$ Gly-Ile). Introduction of $\left[\mathrm{SnMe}_{2} \mathrm{~L}(\mathrm{OH})_{2}\right]^{-}$species into the species matrix resulted in high value of standard deviation, and hence it was ruled out. Further, for all three systems, the last three species as written above were rejected by SCOGS as negative. This confirms that in all the dimethyltin(IV) systems, $1: 1$ metal: ligand complex species are formed in the studied $\mathrm{pH}$ range regardless of metal to ligand ratio which was varied from $1: 1$ to $1: 3$ in the different titration sets.

The complex formation process of $\mathrm{Me}_{2} \mathrm{SnCl}_{2}$ with these dipeptides starts at $\mathrm{pH}=2.9 \pm 0.3$ with the formation of $30-65 \% \mathrm{Me}_{2} \mathrm{Sn}(\mathrm{HL})$ complex, that is, 111 species. This species is formed by the coordination of deprotonated ligand, coordinating through carboxylic oxygen. Furthermore, in all the studied dimethyltin(IV) systems, similar values of formation constant $(\log \beta \sim 10.62 \pm 13)$ observed for this complex 111 species (i.e., $\mathrm{Me}_{2} \mathrm{Sn}(\mathrm{HL})$ for the reaction where $\mathrm{M}=\mathrm{Me}_{2} \mathrm{Sn}^{2+}: \mathrm{M}+\mathrm{H}_{2} \mathrm{~L} \rightleftharpoons \mathrm{M}(\mathrm{HL})+\mathrm{H}$ ) (Table 7) and the similar stepwise stability constants of the species (i.e., when the formation of 111 species is represented as $\mathrm{H}_{2} \mathrm{~L} \rightleftharpoons \mathrm{H}+$ $\mathrm{HL}$; dissociation of the ligand, that is, $\log \beta_{011}$, and $\mathrm{M}+$ $\mathrm{HL} \rightleftharpoons \mathrm{M}(\mathrm{HL}) ; \log \mathrm{K}=\log \beta_{111}-\log \beta_{011} \approx 1.75 \pm 0.14$, see Table 7) are in favor of the formation of monodentate carboxylate coordination in these complexes (Figure 5) in the acidic $\mathrm{pH}$ range $2.9-5.5$. In this case the $\log \mathrm{K}$ value 
TABLe 7: Protonation constants (log K) of the ligands and formation constants $(\log \beta)$ of organotin(IV) complexes and hydrolysis constants of dimethyltin(IV) and trimethyltin(IV) cation at $298 \pm 0.1 \mathrm{~K}, I=0.1 \mathrm{M} \mathrm{KNO}_{3} ; \beta_{p q r}=\mathrm{M}_{p} \mathrm{~L}_{q} \mathrm{H}_{r} /[\mathrm{M}]^{p}[\mathrm{~L}]^{q}[\mathrm{H}]^{r} ; \mathrm{pK} K_{1}=\log \beta_{111}-\log \beta_{110} ; \mathrm{pK} 2$ $=\log \beta_{110}-\log \beta_{11-1} ; \log \mathrm{K}=\log \beta_{111}-\log \beta_{011}$; standard deviations are in parentheses (last digit) ${ }^{\mathrm{a}}$.

\begin{tabular}{|c|c|c|c|}
\hline $\log \beta_{\mathrm{pqr}}$ & $\mathrm{H}_{2}$ Tyr-Ala & $\mathrm{H}_{2}$ Gly-Ala & $\mathrm{H}_{2}$ Gly-Ilu \\
\hline \multicolumn{4}{|c|}{ For $\mathrm{Me}_{2} \mathrm{Sn}(\mathrm{IV})$ Systems } \\
\hline 111 & $10.50(2)$ & $10.57(1)$ & $10.77(2)$ \\
\hline 110 & $6.57(2)$ & $6.11(1)$ & $6.75(1)$ \\
\hline $11-1$ & $2.10(3)$ & $1.40(2)$ & $1.87(3)$ \\
\hline $\mathrm{pK}_{1}$ & 3.93 & 4.46 & 4.02 \\
\hline $\mathrm{pK}_{2}$ & 4.47 & 4.71 & 4.88 \\
\hline $\log K$ & 1.75 & 1.62 & 1.89 \\
\hline \multicolumn{4}{|c|}{ For $\mathrm{Me}_{3} \mathrm{Sn}(\mathrm{IV})$ Systems } \\
\hline 111 & $9.45(2)$ & $10.08(3)$ & $9.84(1)$ \\
\hline 110 & $3.61(1)$ & $4.10(2)$ & $3.95(2)$ \\
\hline $\mathrm{pK}_{1}$ & 5.84 & 5.98 & 5.89 \\
\hline \multicolumn{4}{|c|}{ Proton-Ligand Constants } \\
\hline 011 & $8.75(2)$ & $8.95(1)$ & $8.88(2)$ \\
\hline 012 & $11.50(3)$ & $11.10(2)$ & $11.40(1)$ \\
\hline
\end{tabular}

${ }^{\mathrm{a}}$ The hydrolysis constants of the dimethyltin(IV) cation are as follows: $\log \beta_{10-1}=-3.16(1) ; \log \beta_{10-2}=-8.42(2) ; \log \beta_{10-3}=-19.46(1) ; \log \beta_{20-2}=-4.95(2)$; $\log \beta_{20-3}=-9.79(2)$; for trimethyltin(IV) cation, $\log \beta_{10-1}=-6.18(1) ; \log \beta_{10-2}=-17.80(2)$ [33].

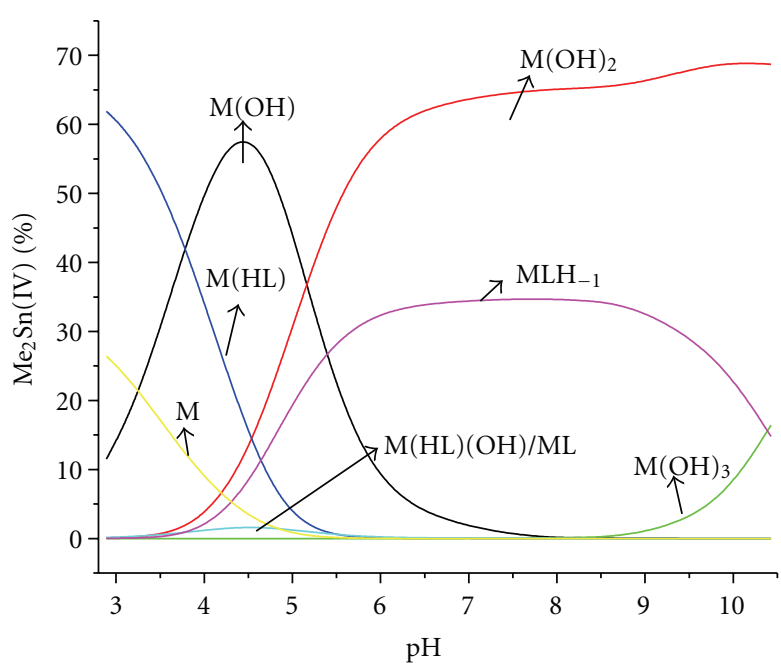

(a)

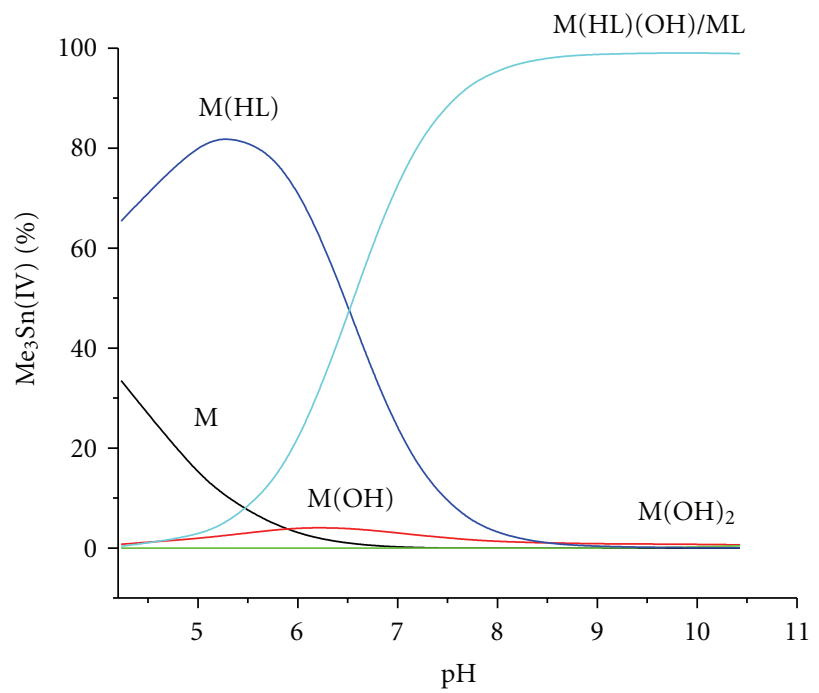

(b)

FIgURE 4: Speciation curves for 1:1 (a) dimethyltin-Tyr-Ala and (b) trimethyltin-HTyr-Ala where $\mathrm{M}=\mathrm{Me}_{2} \mathrm{Sn}^{2+} \mathrm{or} \mathrm{Me}_{3} \mathrm{Sn}^{+}$.

cannot correlate with the $\mathrm{pK}_{a}$ of the carboxylic groups indicating that the stability is affected by several effects (hydrogen bonds, possible interaction with the amide oxygen of peptides, hydrophobic interactions, etc.).

In the studied systems, $\mathrm{Me}_{2} \mathrm{Sn}(\mathrm{HL})$ complex species suffered a deprotonation near $\mathrm{pH}$ range 3.5-6.2 leading to the formation of $\mathrm{ML}$ or $\mathrm{M}(\mathrm{HL})(\mathrm{OH})$ (i.e., 110) species. For this process the observed $\mathrm{pK}_{1}$ values (see Table 7 ) are similar to each other in all the systems and may be attributed to the (i) deprotonation of a metal-bound water molecule forming hydroxo mixed-ligand complexes or (ii) metal-promoted deprotonation of $-\mathrm{NH}_{3}^{+}$group present in zewitterionic form. The $\mathrm{pK}_{1}$ values reported for dimethyltin(IV)-Gly-Gly
[42] and- Ala-Gly [43] are 3.46 and 3.42, respectively, for which the formation of hydroxo mixed-ligand complexes was reported. In the present study the observed $\mathrm{pK}_{1}$ (3.934.46) values also indicate a hydrolytic process takes place during the deprotonation of the carboxylate coordinated $\mathrm{M}(\mathrm{HL})$ complex species, forming a hydroxo mixed-ligand, $\mathrm{M}(\mathrm{HL})(\mathrm{OH})$ (i.e., $\mathrm{COO}^{-}$and $\mathrm{OH}^{-}$are coordinated) complex. However, in the formation of ML species leading to the formation of eight-membered ring which would result in significantly different $\mathrm{pK}$ values. Therefore, on the basis of our results, the formation of ML species can be ruled out. The formation of this hydroxo mixed-ligand complex in acid solution is best described as a transfer of protons 


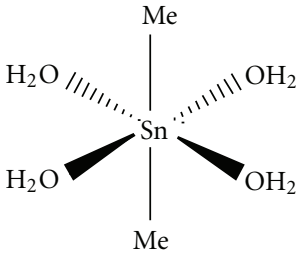

(a)

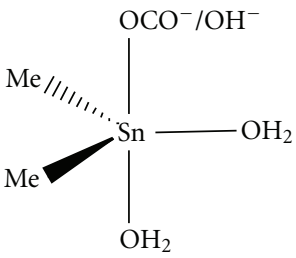

(c)

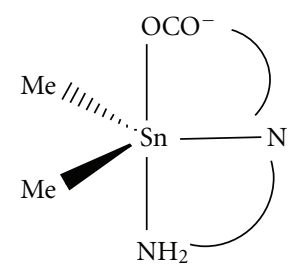

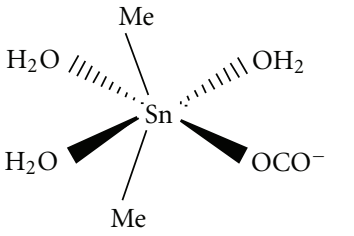

(b1)

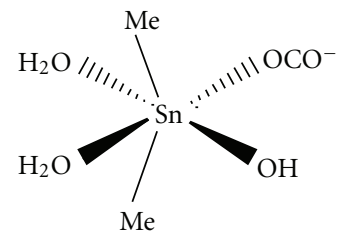

(d)

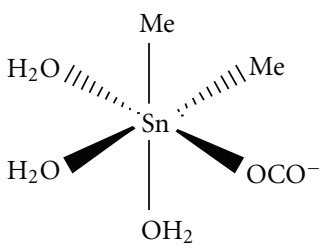

(b2)

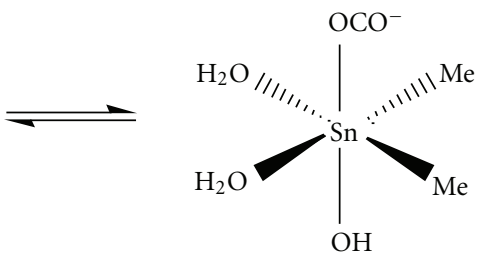

(e)

(f)

Figure 5: Possible geometrical structures of the complex species: $\mathrm{M}$ or $\mathrm{Me}_{2} \mathrm{Sn}\left(\mathrm{H}_{2} \mathrm{O}\right)_{4}^{2+}$ (a); isomers of M(HL) (b1)/(b2); M(HL) or M(OH) (c); isomers of $\mathrm{M}(\mathrm{HL})(\mathrm{OH})(\mathrm{d}) /(\mathrm{e}) ; \mathrm{MLH}_{-1}(\mathrm{f})$.

from water molecules. In such process, metal to oxygen bonds are neither broken nor formed. Consequently, the formation of hydroxo mixed-ligand species represents the detachment of a proton rather than the substitution of water molecules by $\mathrm{OH}^{-}$ions. Further, $\mathrm{M}(\mathrm{HL})(\mathrm{OH})$ species has a comparable affinity for a carboxylate group as well as for aqua ion (Figures 5(b1)/5(b2)), and the carboxylate coordinated species (trigonal-bipyramidal) undergoes water deprotonation (Figure $5(\mathrm{c})$ ). In the studied $\mathrm{pH}$ range the species $\mathrm{M}(\mathrm{OH})$ and $\mathrm{M}(\mathrm{OH})_{2}$ also exist; however, the formation of $\mathrm{M}(\mathrm{OH})_{3}$ starts at $\mathrm{pH} \sim 9$.

The complex $\mathrm{M}(\mathrm{HL})(\mathrm{OH})$ undergoes further deprotonation in the $\mathrm{pH}$ range 4-10 leading to the formation of $\mathrm{MLH}_{-1}$ species $(30-52 \%)\left(\mathrm{M}(\mathrm{HL})(\mathrm{OH}) \rightleftharpoons \mathrm{MLH}_{-1}+\mathrm{H}_{3} \mathrm{O}\right)$. For this process the $\mathrm{pK}_{2}$ values lie in the range $4.67 \pm 0.20$. The observed $\mathrm{pK}_{2}$ values for $\mathrm{MLH}_{-1}$ species are nearly coincident with those reported for the corresponding dimethyltin(IV)Gly-Gly [42] and dimethyltin(IV)-Ala-Gly [43]. In this process the deprotonation of the amide and amine nitrogen takes place in a cooperative manner with the removal of the coordinated hydroxyl group. Therefore, a similar structure has been proposed for $\mathrm{MLH}_{-1}$ in which the coordination occurs via $\left[\mathrm{NH}_{2}, \mathrm{~N}^{-}, \mathrm{COO}^{-}\right]$with a trigonal-bipyramidal geometry in which the equatorial position is occupied by two methyl groups and amide nitrogen (Figure 5(f)).

3.4.2. Trimethyltin(IV)-Dipeptide Systems. In all of the trimethyltin-dipeptide systems, only one species having dipeptide to tin ratio of $1: 1$ has been found irrespective of the dipeptide to tin ratio at which the titration has been carried out. There is no evidence for the formation of polymeric species in the present study. For the trimethyltin systems, the complex formation starts at $\mathrm{pH}$ $4.7 \pm 0.3$ (Figure $4(\mathrm{~b})$ ) to form $58-82 \% \mathrm{Me}_{3} \mathrm{Sn}(\mathrm{HL})$ species (according to equilibrium $\mathrm{Me}_{3} \mathrm{Sn}+\mathrm{H}_{2} \mathrm{~L} \rightleftharpoons \mathrm{Me}_{3} \mathrm{Sn}(\mathrm{HL}$ ) $\left.+\mathrm{H} / \mathrm{H}_{3} \mathrm{O}\right)$. Further, the formation of $\mathrm{Me}_{3} \mathrm{Sn}(\mathrm{HL})$ complex predominates over the hydroxide formation (i.e., $\mathrm{Me}_{3} \mathrm{Sn}+\mathrm{H}_{2} \mathrm{O} \rightleftharpoons \mathrm{Me}_{3} \mathrm{Sn}(\mathrm{OH})+\mathrm{H}_{3} \mathrm{O}$ and $\mathrm{Me}_{3} \mathrm{Sn}(\mathrm{OH})$ $\left.+\mathrm{H}_{2} \mathrm{O} \rightleftharpoons \mathrm{Me}_{3} \mathrm{Sn}(\mathrm{OH})_{2}+\mathrm{H}_{3} \mathrm{O}\right)$ at the early stages of the reaction $(\mathrm{pH}<7.0)$. The extent of the $\mathrm{Me}_{3} \mathrm{Sn}(\mathrm{OH})$ and $\mathrm{Me}_{3} \mathrm{Sn}(\mathrm{OH})_{2}$ species formed is much less (3-8\%) for all the studied trimethyltin(IV) systems as indicated from the speciation curves (Figure $4(\mathrm{~b})$ ). In the $\mathrm{pH}$ range 5.5-10.2, the $\mathrm{Me}_{3} \mathrm{Sn}(\mathrm{HL})$ complexes result in $\mathrm{Me}_{3} \mathrm{Sn}(\mathrm{HL})(\mathrm{OH})$ (via deprotonation of a metal bound water molecule (as shown in Figure 6) $\left(\mathrm{Me}_{3} \mathrm{Sn}(\mathrm{HL})+\mathrm{H}_{2} \mathrm{O} \rightleftharpoons \mathrm{Me}_{3} \mathrm{Sn}(\mathrm{HL})(\mathrm{OH})+\mathrm{H}_{3} \mathrm{O}\right)$, 


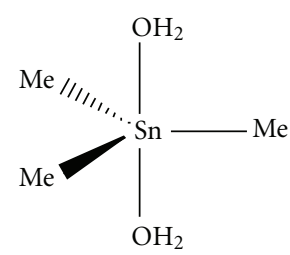

(a)

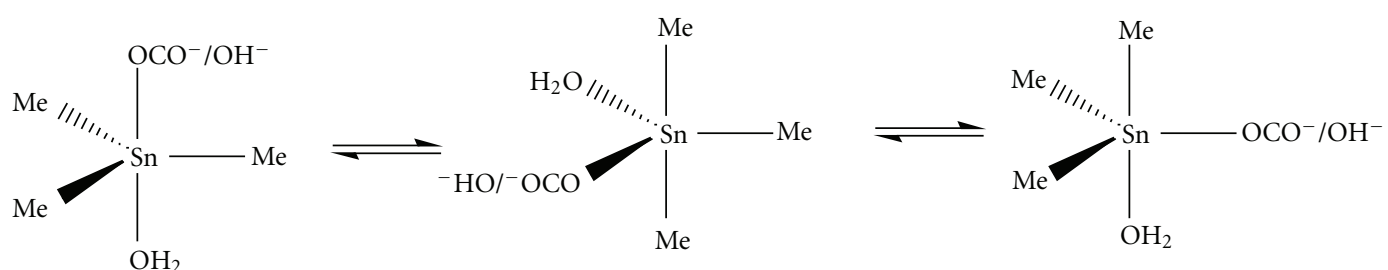

(b)

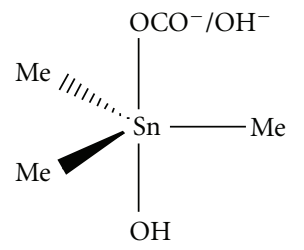

(c)

(d)

(e)

Figure 6: Possible geometrical structures of the complex species: $\mathrm{M}$ or $\mathrm{Me}_{3} \mathrm{Sn}\left(\mathrm{H}_{2} \mathrm{O}\right)_{2}^{+}$(a); isomers of $\mathrm{M}(\mathrm{HL}) / \mathrm{M}(\mathrm{OH})$ (b)-(d); and $\mathrm{M}(\mathrm{HL})(\mathrm{OH})$ or $\mathrm{M}(\mathrm{OH})_{2}(\mathrm{e})$.

which is the predominant species (72-99)\% at this $\mathrm{pH}$ range. Some amount of $\mathrm{Me}_{3} \mathrm{Sn}(\mathrm{HL})(\mathrm{OH})$ is also produced from the monohydroxo species $\mathrm{Me}_{3} \mathrm{Sn}(\mathrm{OH})$ in this $\mathrm{pH}$ range $\left(\mathrm{Me}_{3} \mathrm{Sn}(\mathrm{OH})+\mathrm{H}_{2} \mathrm{~L} \rightleftharpoons \mathrm{Me}_{3} \mathrm{Sn}(\mathrm{HL})(\mathrm{OH})+\mathrm{H}_{3} \mathrm{O}\right)$.

3.5. Conclusions. In the present study, a distorted trigonalbipyramidal structure is proposed for the synthesized diand triorganotin(IV) tyrosylalaninates in the solid state on the basis of the results obtained from the spectroscopic techniques used. Tyrosylalanine acts as dianionic tridentate coordinating through $\left[-\mathrm{C}(\mathrm{O}) \mathrm{O}^{-}\right]$, amino nitrogen $\left(-\mathrm{NH}_{2}\right)$, and $\left[(\mathrm{CO}) \mathrm{N}_{\text {peptide }}^{-}\right]$groups in $\mathrm{R}_{2} \mathrm{Sn}$ (Tyr-Ala) and as monoanionic bidentate coordinating through $\left[-\mathrm{C}(\mathrm{O}) \mathrm{O}^{-}\right.$ and $\left.-\mathrm{NH}_{2}\right]$ groups in the case of $\mathrm{R}_{3} \mathrm{Sn}(\mathrm{HTyr}-\mathrm{Ala})$. In diorganotin(IV) tyrosylalaninates, it is proposed that the two organic groups and peptide nitrogen $\left(\mathrm{N}_{\text {peptide }}^{-}\right)$are in the equatorial positions, while the two axial positions are occupied by the carboxylic oxygen $\left[-\mathrm{C}(\mathrm{O}) \mathrm{O}^{-}\right]$and the amino nitrogen $\left(\mathrm{NH}_{2}\right)$ atom from the same ligand molecule in the distorted trigonal-bipyramidal geometry around tin in solid state. However, a carboxylate and an amino group of two adjacent molecules coordinate at axial position in case of $\mathrm{Me}_{3} \mathrm{Sn}$ (HTyr-Ala), and for $\mathrm{Ph}_{3} \mathrm{Sn}$ (HTyrAla), the carboxylate and amino groups of the same ligand molecule are coordinated to tin. The equilibrium studies of $\mathrm{Me}_{2} \mathrm{Sn}(\mathrm{IV})$ - and $\mathrm{Me}_{3} \mathrm{Sn}(\mathrm{IV})$-dipeptide systems suggest that the carboxylate group is bound to the metal ion in acidic $\mathrm{pH}$. For $\mathrm{Me}_{2} \mathrm{Sn}(\mathrm{IV})$-dipeptide systems, the carboxylate group acts as an anchoring group for the metal-promoted deprotonation of the amide nitrogen (assistied by chelate formation). It has been found that in these dipeptide ligands, $\left[-\mathrm{C}(\mathrm{O}) \mathrm{O}^{-}, \mathrm{N}^{-}, \mathrm{NH}_{2}\right]$ coordinated complexes are dominant in the neutral $\mathrm{pH}(6-8)$ range with a trigonal-bipyramidal structure. Therefore, it can be concluded that $\mathrm{R}_{n} \mathrm{Sn}^{(4-n)+}$ ( $n=2$ and 3 ) species may interact strongly with the $\mathrm{O} / \mathrm{N}$ donor groups of the protein and can effectively disturb DNA duplication process, and the interaction of organotin(IV) moiety with tyrosylalanine may serve as model for metalprotein interactions.

\section{Acknowledgments}

The authors are thankful to the Head, Regional Sophisticated Instrumentation Centre, Central Drug Research Institute, Lucknow, India, for providing ${ }^{1} \mathrm{H}$ and ${ }^{13} \mathrm{C}$ NMR spectra. One of the authors (Ms. S. Sulaxna) is thankful to the Council of Scientific and Industrial Research, New Delhi, India, for awarding her the Senior Research Fellowship. Financial support for ${ }^{119} \mathrm{Sn}$ Mössbauer work from the National Institute of Biomedical Research Support Program (MBRS/SCORE, GM08005) is gratefully acknowledged. 


\section{References}

[1] M. Nath, S. Pokharia, and R. Yadav, "Organotin(IV) complexes of amino acids and peptides," Coordination Chemistry Reviews, vol. 215, no. 1, pp. 99-149, 2001.

[2] L. Pellerito and L. Nagy, "Organotin(IV) ${ }^{n+}$ complexes formed with biologically active ligands: equilibrium and structural studies, and some biological aspects," Coordination Chemistry Reviews, vol. 224, no. 1-2, pp. 111-150, 2002.

[3] M. Gielen, "Organotin compounds and their therapeutic potential: a report from the Organometallic Chemistry Department of the Free University of Brussels," Applied Organometallic Chemistry, vol. 16, no. 9, pp. 481-494, 2002.

[4] M. Gielen, "Tin-based antitumour drugs," Coordination Chemistry Reviews, vol. 151, pp. 41-51, 1996.

[5] C. Pettinari and F. Marchetti, "Chemical and Biotechnological Developments in organotin cancer compounds," in Tin Chemistry, Fundamentals, Frontiers, and Applications, A. G. Davies, M. Gielen, K. H. Pannell, and E. R. T. Tiekink, Eds., pp. 454468, John Wiley \& Sons, New York, NY, USA, 2008.

[6] M. D. Couce, G. Faraglia, U. Russo, L. Sindellari, and G. Valle, "Synthesis, characterisation and X-ray crystal structures of diorganotin(IV) complexes with 2-mercaptopyridine derivatives," Journal of Organometallic Chemistry, vol. 513, no. 1-2, pp. 77-83, 1996.

[7] M. Nath, R. Yadav, G. Eng, and P. Musingarimi, "Characteristic spectral studies and in vitro antimicrobial and in vivo multi-infection antifungal activities in mice of new organotin(IV) derivatives of heterocyclic amino acids," Applied Organometallic Chemistry, vol. 13, no. 1, pp. 29-37, 1999.

[8] M. J. Clarke, F. Zhu, and D. R. Frasca, "Non-platinum chemotherapeutic metallopharmaceuticals," Chemical Reviews, vol. 99, no. 9, pp. 2511-2533, 1999.

[9] M. Nath, R. Yadav, G. Eng, and P. Musingarimi, "Synthesis, spectral studies, in vitro antimicrobial and in vivo multiinfection antifungal activities in mice of new organotin(lv) derivatives of amino acids," Journal of Chemical ResearchPart S, no. 8, pp. 1730-1743, 1998.

[10] M. Nath and R. Yadav, "Spectral studies and in vitro antimicrobial activity of new organotin(IV) complexes of Schiff bases derived from amino acids," Bulletin of the Chemical Society of Japan, vol. 70, no. 6, pp. 1331-1337, 1997.

[11] M. Nath, R. Jairath, G. Eng, X. Song, and A. Kumar, "Synthesis, spectral characterization and biological studies of some organotin(IV) complexes of l-proline, trans-hydroxy-1proline and l-glutamine," Spectrochimica Acta-Part A, vol. 62, no. 4-5, pp. 1179-1187, 2005.

[12] M. Nath, S. Pokharia, G. Eng, X. Song, and A. Kumar, "Comparative study of structure-activity relationship of di- and triorganotin(IV) derivatives of amino acid and peptides," Journal of Organometallic Chemistry, vol. 669, no. 1-2, pp. 109-123, 2003.

[13] S. E. Castillo-Blum and N. Barba-Behrens, "Coordination chemistry of some biologically active ligands," Coordination Chemistry Reviews, vol. 196, no. 1, pp. 3-30, 2000.

[14] M. Nath, S. Pokharia, G. Eng, X. Song, and A. Kumar, "Diorganotin(IV) derivatives of dipeptides containing at least one essential amino acid residue: synthesis, characteristic spectral data, cardiovascular, and anti-inflammatory activities," Synthesis and Reactivity in Inorganic and Metal-Organic Chemistry, vol. 34, no. 10, pp. 1689-1708, 2004.

[15] M. A. Girasolo, T. Pizzino, C. Mansueto, G. Valle, and G. C. Stocco, "Spectroscopic characterization and biological activity of L-methionyl-L histidinato complexes of
$\mathrm{R}_{2} \mathrm{Sn}(\mathrm{IV})$ ions $(\mathrm{R}=\mathrm{Me}, \mathrm{nBu}, \mathrm{Ph})$ and $\mathrm{X}$-ray structure of $\mathrm{Me}_{2} \mathrm{SnMetHis} \cdot 0.5 \mathrm{MeOH}$," Applied Organometallic Chemistry, vol. 14, no. 4, pp. 197-211, 2000.

[16] M. Nath, H. Singh, P. Kumar, A. Kumar, X. Song, and G. Eng, "Organotin(IV) tryptophanylglycinates: potential nonsteroidal anti-inflammatory agents; crystal structure of dibutyltin(IV) tryptophanylglycinate," Applied Organometallic Chemistry, vol. 23, no. 9, pp. 347-358, 2009.

[17] M. Nath, S. Pokharia, X. Song et al., "New organotin(IV) derivatives of dipeptides as models for metal-protein interactions: in vitro anti-tumour activity," Applied Organometallic Chemistry, vol. 17, no. 5, pp. 305-314, 2003.

[18] M. Nath, R. Yadav, G. Eng, T. T. Nguyen, and A. Kumar, "Characteristic spectral studies, and antimicrobial and antiinflammatory activities of diorganotin(IV) derivatives of dipeptides," Journal of Organometallic Chemistry, vol. 577, no. 1, pp. 1-8, 1999.

[19] M. Nath, S. Pokharia, G. Eng et al., "New trimethyltin(IV) derivatives of dipeptides: synthesis, characteristic spectral studies and biological activity," Applied Organometallic Chemistry, vol. 18, no. 9, pp. 460-470, 2004.

[20] M. Nath, H. Singh, G. Eng, and X. Song, "New di- and triorganotin(IV) derivatives of tyrosinylphenylalanine as models for metal-protein interactions: synthesis and structural characterization. Crystal structure of $\mathrm{Me}_{2} \mathrm{Sn}$ (Tyr-Phe) · $\mathrm{MeOH}$," Journal of Organometallic Chemistry, vol. 693, no. 15, pp. 2541-2550, 2008.

[21] M. Nath, S. Pokharia, G. Eng, X. Song, and A. Kumar, "New triorganotin(IV) derivatives of dipeptides as antiinflammatory- antimicrobial agents," European Journal of Medicinal Chemistry, vol. 40, no. 3, pp. 289-298, 2005.

[22] M. Nath, S. Pokharia, G. Eng, X. Song, and A. Kumar, "New triorganotin (IV) derivatives of dipeptides as models for metal-protein interactions: synthesis, structural characterization and biological studies," Spectrochimica Acta-Part A, vol. 63, no. 1, pp. 66-75, 2006.

[23] M. Nath, H. Singh, G. Eng, and X. Song, "New diorganotin(IV) derivatives of dipeptides: synthesis and characteristic spectral studies," Spectrochimica Acta-Part A, vol. 71, no. 2, pp. 529-536, 2008.

[24] M. Nath, H. Singh, G. Eng, and X. Song, "Mössbauer spectral studies of di- and triorganotin(IV) histidinylleucinates," Hyperfine Interactions, vol. 185, no. 1-3, pp. 69-79, 2008.

[25] G. Ruisi, M. T. Lo Giudice, F. Huber, and M. Vornefeld, "Diand tri-organotin(IV) complexes of N-acetyltriglycine and $\mathrm{N}$ benzoyltriglycine: synthesis and spectroscopic characterization," Applied Organometallic Chemistry, vol. 10, no. 10, pp. 779-790, 1996.

[26] F. Capolongo, A. M. Giuliani, M. Giomini, and U. Russo, "Interactions of organotin(IV) halides with reduced glutathione in aqueous solution," Journal of Inorganic Biochemistry, vol. 49, no. 4, pp. 275-293, 1993.

[27] R. Barbieri and M. T. Musmeci, "A ${ }^{119}$ Sn mossbauer spectroscopic study on the interaction of dimethyltin(IV) derivatives with rat hemoglobin, and of related model systems in aqueous solution," Journal of Inorganic Biochemistry, vol. 32, no. 2, pp. 89-108, 1988.

[28] G. Guli, G. Gennaro, L. Pellerito, and G. C. Stocco, "Diorganotin(IV) dipeptide complexes with potential antitumour activity," Applied Organometallic Chemistry, vol. 7, no. 6, pp. 407-412, 1993.

[29] A. Jancsô, B. Henry, P. Rubini, G. Vankö, and T. Gajda, "Dimethyltin(IV) cation induced amide deprotonation of aspartic 
acid containing dipeptides," Journal of the Chemical Society, Dalton Transactions, no. 12, pp. 1941-1947, 2000.

[30] A. Jancsó, T. Gajda, A. Szorcsik et al., "Potentiometric and spectroscopic studies on the dimethyltin(IV) complexes of 2hydroxyhippuric acid," Journal of Inorganic Biochemistry, vol. 83, no. 2-3, pp. 187-192, 2001.

[31] R. C. Poller, The Chemistry of Organotin Compounds, Logos Press, London, UK, 1970.

[32] M. Nath, Sulaxna, X. Song, and G. Eng, "Organotin(IV) triazolates: synthesis and their spectral characterization," Journal of Organometallic Chemistry, vol. 691, no. 8, pp. 16491657, 2006.

[33] M. Nath and Sulaxna, "Potentiometric and multinuclear NMR investigations of di-/trimethyltin(IV) cations with some heterocyclic thiones in aqueous media," New Journal of Chemistry, vol. 31, no. 3, pp. 418-428, 2007.

[34] L. J. Bellamy, Advances in Infrared Group Frequencies, Methuen, London, UK, 1968.

[35] R. V. Parish and C. E. Johnson, "Studies in Mössbauer spectroscopy. Part IV. Signs of the quadrupole coupling constants for some organotin(IV) compounds," Journal of the Chemical Society A, pp. 1906-1910, 1971.

[36] L. E. Khoo, J. P. Charland, E. J. Gabe, and F. E. Smith, "Synthesis and structural studies for a series of aromatic Schiff base complexes with triphenyltin chloride and triphenyltin isothiocyanate," Inorganica Chimica Acta, vol. 128, no. 2, pp. 139-145, 1987.

[37] B. Y. K. Ho and J. J. Zuckerman, "Trialkyltin derivatives of amino acids and dipeptides," Inorganic Chemistry, vol. 12, no. 7, pp. 1552-1561, 1973.

[38] J. P. Greenstein and M. Winitz, Chemistry of the Amino Acids, vol. 2, John Wiley \& Sons, New York, NY, USA, 1961.

[39] T. P. Lockhart and W. F. Manders, "Structure determination by NMR spectroscopy. Correlation of $\left|{ }^{2} \mathrm{~J}\left({ }^{119} \mathrm{Sn}, 1 \mathrm{H}\right)\right|$ and the Me-Sn-Me angle in methyltin(IV) compounds," Inorganic Chemistry, vol. 25, no. 7, pp. 892-895, 1986.

[40] J. Holecek, M. Nadvornik, K. Handlir, and A. Lyčka, " ${ }^{13} \mathrm{C}$ and ${ }^{119}$ Sn NMR spectra of di-n-butyltin(IV) compounds," Journal of Organometallic Chemistry, vol. 315, no. 3, pp. 299-308, 1986.

[41] G. Arena, A. Contino, S. Musumeci, and R. Purrello, "Formation and stability constants of dimethyltin(IV) complexes with citrate, tripolyphosphate, and nitrilotriacetate in aqueous solution," Journal of the Chemical Society, Dalton Transactions, no. 11, pp. 3383-3387, 1990.

[42] P. Surdy, P. Rubini, N. Buzás, B. Henry, L. Pellerito, and T. Gajda, "Interaction of dimethyltin(IV) ${ }^{2+}$ cation with gly-gly, gly-his, and some related ligands. A new case of a metal ion able to promote peptide nitrogen deprotonation in aqueous solution," Inorganic Chemistry, vol. 38, no. 2, pp. 346-352, 1999.

[43] K. Gajda-Schrantz, A. Jancsó, C. Pettinari, and T. Gajda, "Thiolate anchor in organotin(IV) induced amide deprotonation: equilibrium and NMR spectroscopic studies on dimethyltin(IV) complexes formed with N-(2-mercaptopropionyl)glycine and L-alanyl-glycine," Dalton Transactions, no. 14, pp. 2912-2916, 2003.

[44] T. K. Sham and G. M. Bancroft, "Tin-119 Mössbauer quadrupole splittings for distorted $\mathrm{Me}_{2} \mathrm{Sn}$ (IV) structures," Inorganic Chemistry, vol. 14, no. 9, pp. 2281-2283, 1975. 


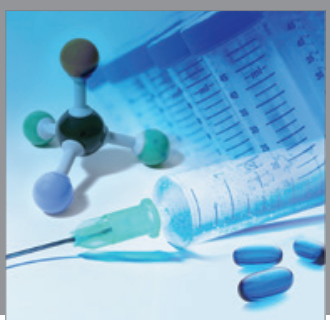

International Journal of

Medicinal Chemistry

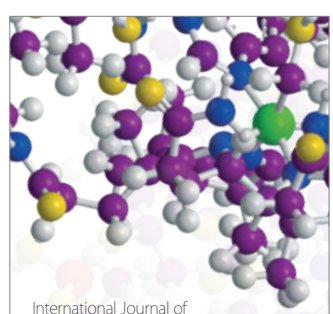

Carbohydrate Chemistry

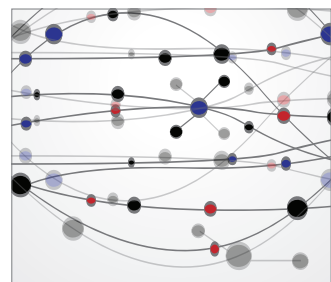

The Scientific World Journal
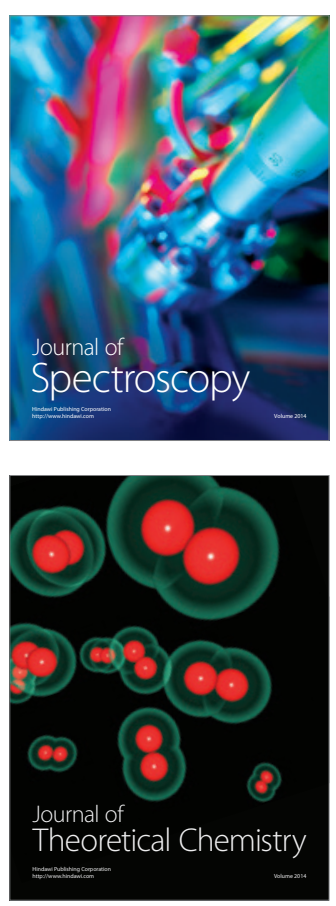
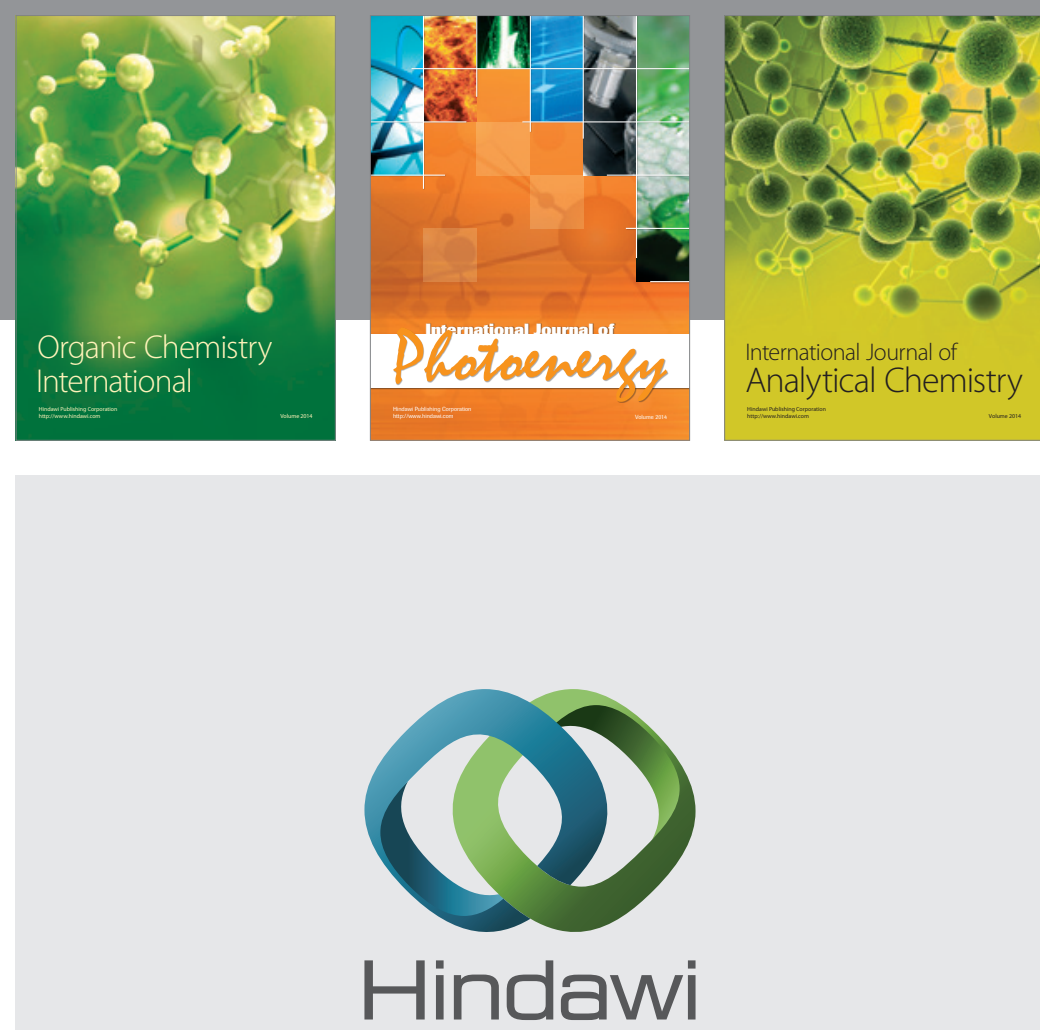

Submit your manuscripts at

http://www.hindawi.com
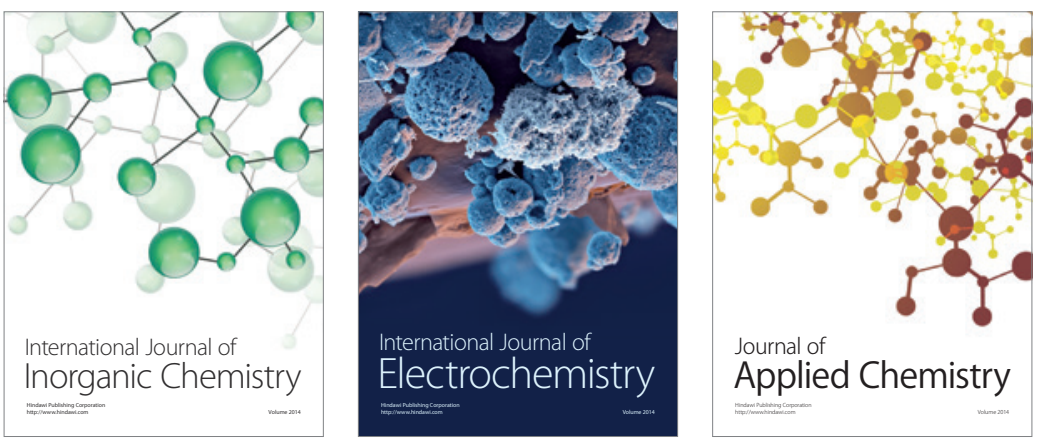

Journal of

Applied Chemistry
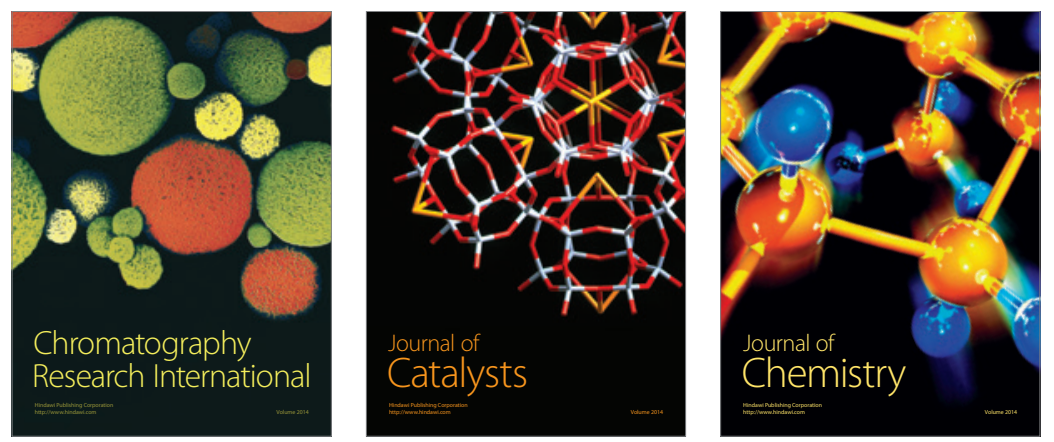
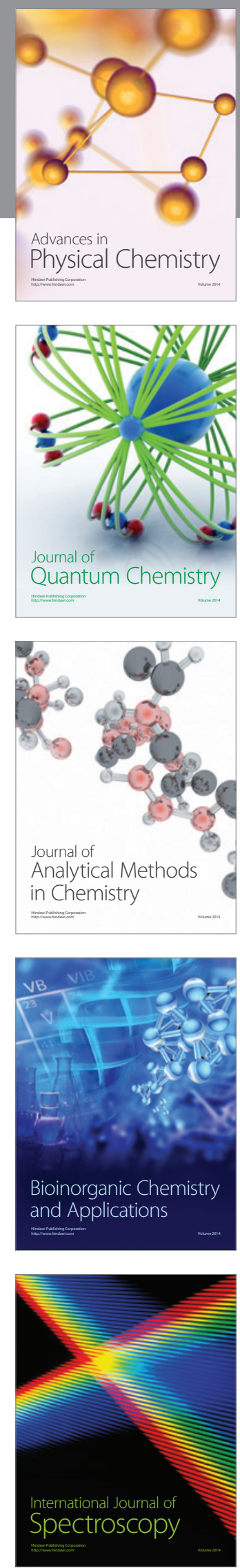